\title{
Peripheral Sensory Axon Growth: From Receptor Binding to Cellular Signaling
}

\author{
Budd A. Tucker, Karen M. Mearow
}

\begin{abstract}
Regeneration following axonal injury of the adult peripheral sensory nervous system is heavily influenced by factors located in a neuron's extracellular environment. These factors include neurotrophins, such as Nerve Growth Factor (NGF) and the extracellular matrix, such as laminin. The presence of these molecules in the peripheral nervous system (PNS) is a major contributing factor for the dichotomy between regenerative capacities of central vs. peripheral neurons. Although PNS neurons are capable of spontaneous regeneration, this response is critically dependent on many different factors including the type, location and severity of the injury. In this article, we will focus on the plasticity of adult dorsal root ganglion (DRG) sensory neurons and how trophic factors and the extracellular environment stimulate the activation of intracellular signaling cascades that promote axonal growth in adult dorsal root ganglion neurons.
\end{abstract}

RÉSUMÉ: Croissance des axones sensitifs périphériques : de la liaison au récepteur à la signalisation cellulaire. La régénérescence axonale suite à une lésion du système nerveux sensitif chez l'adulte est très influencée par des facteurs localisés dans l'environnement extracellulaire du neurone, dont les neurotropines comme le facteur de croissance nerveuse (NGF) et la matrice extracellulaire comme la laminine. La présence de ces molécules dans le système nerveux périphérique (SNP) est un facteur majeur contribuant à la dichotomie entre la capacité de régénérescence des neurones centraux et périphériques. Bien que les neurones du SNP soient capables de régénérescence spontanée, cette réponse est intimement dépendante de plusieurs facteurs différents, dont le type, la localisation et la sévérité de la lésion. Dans cet article nous traitons de la plasticité des neurones sensitifs du ganglion de la racine postérieure chez l'adulte et de la façon dont les facteurs trophiques et l'environnement extracellulaire stimulent l'activation des cascades de signalisation intracellulaire qui activent la croissance axonale dans les neurones des ganglions de la racine postérieure chez l'adulte.

Can. J. Neurol. Sci. 2008; 35: 551-566

The ability of neurons to regenerate their axons after damage is a function of a number of different parameters. It is known that various elements can influence and promote regeneration of peripheral axons. The neuronal response (both sensory and motor) to peripheral nerve injury has been studied for more than a century, and while it seems obvious that there must be some coordinated response of cellular signaling cascades resulting in the observed regenerative processes, most aspects of regeneration-associated intracellular signaling remain poorly understood. In addition to soluble factors (neurotrophins, cytokines and other growth factors), the extracellular environment in which growth occurs is critically important. It is generally accepted that axonal regeneration in the central nervous system (CNS) does not occur to any great extent, and that this is due to a number of factors, the most prominent being a non-permissive growth environment, as well as an unavailability of appropriate growth-promoting factors. In the peripheral nervous system (PNS), on the other hand, peripheral axons (both motor and sensory) generally regenerate quite well, relative to CNS axons. Elucidating neuronal growth or regeneration programs in PNS neurons, both in terms of neurotrophin responsiveness and effects of permissive growth environments, is likely to also provide insight into ways of enhancing CNS repair.

From the Department of Ophthalmology, Schepens Eye Research Institute (BAT), Harvard Medical School, Boston, MA, USA; Division of BioMedical Sciences (KMM), Memorial University of Newfoundland, St. John's, NL, Canada. Received February 1, 2008. Final Revisions Submitted May 7, 2008. Correspondence to: K.M. Mearow, Div BioMedical Sciences - M5352, Faculty of Medicine, Memorial University of Newfoundland, 300 Prince Philip Dr, St. John's, Newfoundland, A1B 3V6, Canada. 
In this review we will focus on in vitro models used to investigate factors involved in promoting axonal growth from mature sensory neurons with emphasis on extracellular cues and associated intracellular signaling pathways and will attempt to summarize how integrin-activated signaling pathways synergize with growth factor-activated pathways to result in optimal axonal regrowth. Over the last several years there has been an increasing interest and awareness of the role that integrins can play in regulating neuronal survival and axonal regeneration..$^{1-3}$ These different ligand-activated signaling cascades have many common components, and it is becoming clear that there is crosstalk between them, with the final outcome dependent upon an appropriate balance between critical components.

\subsection{The peripheral nerve and injury/regeneration}

The PNS encompasses all nerves that lie peripheral to the pial covering of the CNS and include the craniospinal and autonomic nerves, and are composed of both motor and sensory fibres (Figure 1). Peripheral spinal nerves are covered by the outer epineurium; inside the epineurium, the perineurium covers bundles of individual fibers, which are filled with an intrafascicular connective tissue called the endoneurium. The epineurium provides the major structural support for the peripheral nerve and is made up of fibroblasts, collagen and fat. The perineurial layer is made up of alternating layers of flattened polygonal cells derived from fibroblast and collagen and between these layers is the basal lamina that contains important growth promoting molecules that will be discussed in later sections. The endoneurium is made of mostly type 1 collagen fibers and is found adjacent to individual Schwann cell-axon units. Between these units and the endoneurium lies another basal lamina layer.

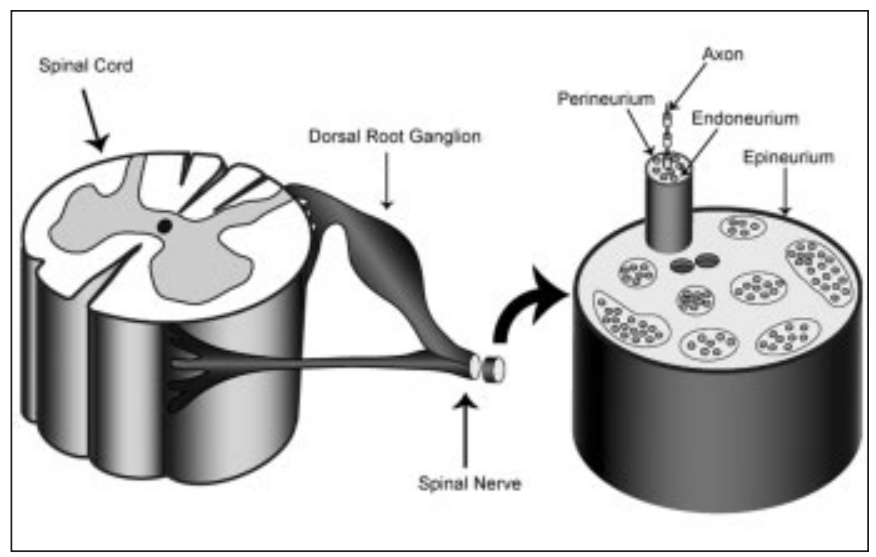

Figure 1: Anatomy of the peripheral nerve. Illustration depicting the location of a dorsal root ganglion (DRG) in relation to the spinal cord and a spinal nerve. Sensory neuron cell bodies are located in the DRG with the central processes entering the spinal cord via the dorsal root, while the peripheral processes exit to the periphery in a spinal nerve along with motor processes from the ventral roots. The peripheral nerve is made up of three connective tissue layers: the outermost epineurium, the middle perineurium and the innermost endoneurium.
Peripheral nerve injuries have been classically characterized by the severity of the injury. Crush injuries with differing degrees of axon damage generally have the best prognosis for recovery, since there is little, if any, disruption of the integrity of the nerve or the axons themselves. Recovery of function is relatively good in these circumstances. In more severe damage, where a nerve has been completely transected, there is no continuity between the proximal and distal portions, and while regeneration of the proximal processes can occur, reinnervation of the peripheral targets requires surgical apposition of the damaged nerve ends. However, such reinnervation is generally compromised to some degree with resulting difficulties in recovery of function. ${ }^{4-7}$

\subsection{Environmental influences on neuronal regeneration}

The CNS environment has long been known to have an inhibitory influence on axonal growth, ${ }^{8-11}$ with myelin components such as myelin-associated glycoprotein, ${ }^{12}$ the inhibitory molecule Nogo ${ }^{13,14}$ and the oligodendrocyte-myelin glycoprotein (OMgp) signaling to prevent regeneration. Chondroitin sulfate proteoglycans (CSPGs) are important components of the extracellular matrix (ECM), and also generally act as inhibitors of axonal growth or regeneration..$^{15-17}$

The PNS environment is considered permissive to axonal growth, of both PNS and CNS axons. While there are a number of components of the PNS growth environment that could play a role in promoting regeneration, one component that is clearly stimulatory to axonal growth is laminin. It was postulated that the presence of laminin in PNS myelin is able to mask the inhibitory influences of myelin-associated glycoprotein, and indeed, laminin has also been shown to be able to overcome the inhibitory influences of CNS myelin and CSPGs on axonal growth. ${ }^{18,19}$

Numerous studies have demonstrated that laminin is a potent stimulator of neurite growth from various classes of CNS and PNS neurons, as well as a variety of cell lines such as PC12 cells and neuroblastoma cells. ${ }^{20-22}$ In addition to laminin, other ECM molecules, such as collagen and fibronectin also play a role in peripheral nerve regeneration. ${ }^{23,24} \mathrm{~A}$ number of recent articles discuss approaches to enhancing peripheral nerve regeneration (eg., ${ }^{25-28}$ ).

\section{Experimental models: Mature sensory neurons}

In this section we will review some of the different in vitro models used to investigate axonal growth or regeneration; we will restrict our discussion to studies employing mature dorsal root ganglion (DRG) sensory neurons. One of the advantages of using mature sensory neurons is that they do not require neurotrophins or ECM molecules for their in vitro survival, although such factors clearly influence the axonal growth responses of these neurons.

\subsection{Peripheral DRG neurons}

Sensory neurons whose axons convey information from the periphery to the spinal cord are located in the DRG (Figures $1,2)$. Dorsal root ganglion neurons are pseudounipolar with spherical cell bodies that vary in diameter and are surrounded by small round satellite cells. A single axon that arises from these neurons exits the cell body and bifurcates, sending one process 

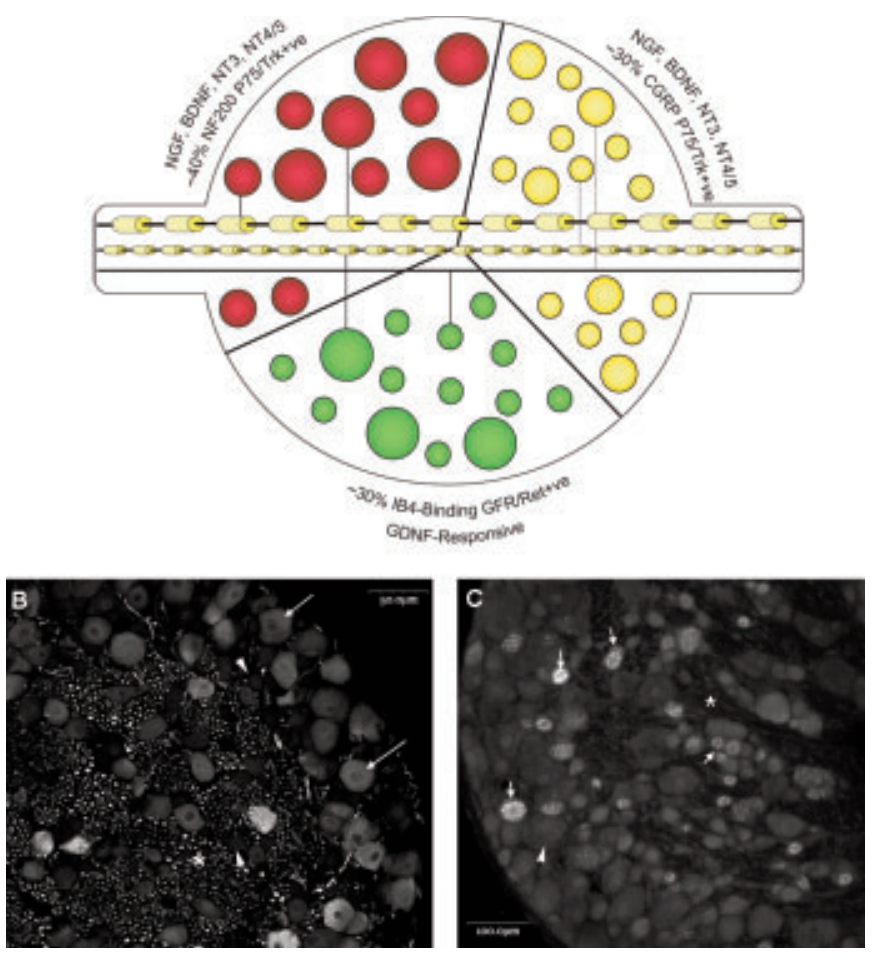

Figure 2: Distribution of the major populations of sensory neurons that comprise the DRG. A. Schematic illustrating the general distribution of the large diameter neurons with myelinated axons (NF200+ve, p75/Trk $+v e)$, the small and medium diameter peptidergic neurons $(C G R P+v e$, $p 75 / T r k+v e)$ and the small non-peptidergic neurons (IB4+ve, GFR/Ret $+v e)$. B. Section of an adult rat DRG immunostained for neurofilament RT97; arrows indicate large stained neurons, while arrowheads denote small unstained neurons. The * indicates the area of the neuropil and positively stained axons which appear as dots in the cross-section. C. Section of an adult rat DRG immunostained for CGRP showing some intensely small-medium sized labeled neurons (arrows) as well as larger unlabeled neurons (arrowhead). Scale bar - A, $50 \mu \mathrm{m} ; \mathrm{B}, 100 \mu \mathrm{m}$.

centrally to form a synapse in the dorsal aspect of the spinal cord via the dorsal root entry zone, while the other process goes peripherally to innervate the skin, muscle and visceral organs. ${ }^{29}$ Thus, the sensory message is carried from the periphery to the CNS via a single extensive axon that essentially bypasses the cell body, which makes up less than $1 \%$ of the cell's cytoplasm and acts to supply protein and energy to the lengthy axon. ${ }^{29}$

The mature mammalian DRG (we will refer primarily to the rat DRG in this review) is made up of a heterogeneous population of cells subdivided on the basis of neurochemistry, morphology, trophic requirements and sensory modalities. ${ }^{30-34}$ While three major cell groups are often described, it should be noted that there is significant overlap among the populations. As shown in Figure 2, the first group (denoted in red) contains roughly $30-40 \%$ of the cells within the lumbar DRGs. This population comprises the large and medium diameter neurons, and is usually identified based on the expression of the heavy chain neurofilament, NF200 (NF200+ve). These neurons typically have large myelinated axons and function as mechanoreceptors and proprioceptors. With regards to receptor expression, the NF200+ve neurons express TrkA and TrkC, as well as the p75NTR. ${ }^{30,33-35}$

The other two major groups consist of either peptidergic, (expressing calcitonin gene related peptide, CGRP+ve, denoted in yellow), or non-peptidergic neurons (binding the lectin Griffonia Simplicifolia IB4, IB4+ve, denoted in green). ${ }^{30,33,34}$ Most of the neurons in the peptidergic group are small with unmyelinated fibres of the C-fibre group. However, there is another group of peptidergic neurons that are medium-sized with small myelinated (A $\delta$ ) fibres. The peptidergic population represents roughly $40 \%$ of the cells within the DRG and neurons preferentially respond to nerve growth factor (NGF). ${ }^{30,33,34}$ However, some of the CGRP-expressing neurons also respond to GDNF. ${ }^{36}$

The IB4-binding population also contains roughly $30 \%$ of the cells within the DRG and are primarily small diameter neurons with unmyelinated axons. These neurons are generally reported to have neither the p75 nor Trk receptors, but instead express the receptor tyrosine kinase RET and one of the GFR $\alpha$ subunits, which makes these cells responsive to GDNF. ${ }^{37,38}$ However, other reports indicate that $>60 \%$ of the neurons express mRNA for Ret, and some of these cells also expressed TrkA, B, or C mRNA. ${ }^{39}$ This cooexpression of Trks in IB4+ve cells may be a developmental holdover, since during development about $80 \%$ of rodent DRG neurons express TrkA at embryonic day(d)18, but by postnatal $\mathrm{d} 2$ there is a switch from NGF to GDNF dependence (with a corresponding alteration in receptor expression). ${ }^{37}$

Approximately, 50-70\% of the neurons express one or more of the high affinity neurotrophin receptors TrkA, TrkB or TrkC. The reported expression of the Trk receptors tends to vary depending upon the spinal level of the DRGs examined, and the percentages of neurons reported as expressing one of these receptors also varies according to different studies. It is generally accepted that about $40-45 \%$ of lumbar DRG neurons express TrkA, and about $20 \%$ of these also express TrkC. TrkC expressing neurons range from $15-20 \%$ of the total, while the numbers for TrkB are much more variable ranging from $5-30 \% .^{33,40-43}$ This variability may be related to whether neurons expressing only TrkB or coexpressing TrkB with other Trks were enumerated. ${ }^{40}$ Neurons expressing only TrkB represent less than $10 \%$ of the total population of neurons in the lumbar DRG, and fewer in the thoracic DRGs. In cultures of dissociated DRG neurons (which comprise neurons from DRGs from all spinal levels) the percentages of neurons expressing neurotrophin receptors is quite similar to that reported for DRG sections. ${ }^{32,44}$

While the Trk family of receptors act as high affinity receptors for the neurotrophins (NGF, BDNF and NT3), the p75NTR is capable of binding all the neurotrophins, as well as serving as a receptor for the proneurotrophins. ${ }^{45}$ It is expressed on all neurotrophin-responsive neurons, but does not appear to be expressed by the IB4+ve, GDNF responsive cells. The roles of p75NTR are quite varied ranging from enhancing Trk activation, to promoting apoptosis and inhibiting neurite growth. ${ }^{46-51}$

Like NGF, the GDNF family of trophic factors exerts its actions by binding to two separate cell surface receptors. The receptor GFR- $\alpha$ is the high affinity growth factor receptor responsible for ligand specificity. ${ }^{52,53}$ Although binding to the GFR- $\alpha$ receptor alone has been shown to stimulate ${ }^{54}$ internal 
signaling cascades, it is commonly accepted that this GPI-linked receptor signals via activation of the second GDNF receptor, RET. ${ }^{53,55-57}$

\subsection{In vitro models for the investigation of factors involved in DRG axonal growth and regeneration}

Peripheral axonal regeneration requires sufficient supply of various trophic (supporting survival) and tropic (directional) factors, which are usually supplied by the local environment including the Schwann cells and the extracellular matrix within the nerve trunks. However, the complexity of the in vivo situation makes it difficult to study cellular and molecular mechanisms that regulate axon growth. In order to investigate mechanisms associated with such events, it has been necessary to take a reductionist approach and use in vitro systems to examine the contribution or requirement of individual components and how these might act together in order to promote growth. As adult DRG neurons survive in the absence of added trophic factors (unlike embryonic or early postnatal DRG neurons), they are a useful model to study the effects of various experimental treatments on axonal growth in the absence of potential confounding effects on neuronal survival.

Different in vitro models have been used in such investigations, each having its own advantages and disadvantages. Explant cultures tend to be the easiest to prepare
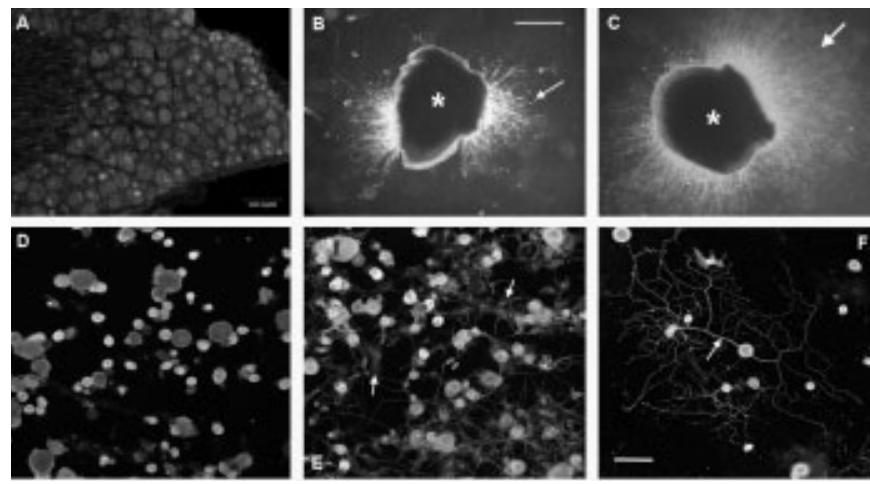

Figure 3: DRG culture models. A. Cross section of an adult rat DRG showing arrangment of neurons in vivo. B, C. Examples of whole DRG explants plated on a laminin-coated culture surface with either no added trophic factors $(B)$ or with the addition of $25 \mathrm{ng} / \mathrm{ml} \mathrm{NGF}(C)$ for $24 \mathrm{hrs}$. Arrow denotes the extent of neurite outgrowth from the ganglion explant. $D-F$. Examples of cultures of enzymatically dissociated DRG neurons culture in defined medium in the absence of added trophic factors. D. Dissociated neurons plated on polylysine substrate, fixed and stained at 6 hrs post-plating. Note the characteristic distribution of small, medium and large sized neurons. Image is a merged image of two confocal channels showing RT97 (lighter gray) and CGRP (brighter cells) immunostaining. E. Example of a relatively densely plated culture plated on laminin fixed and immunostained at 24 hrs after plating. In this example, there are numerous non-neuronal cells present (arrows) making it somewhat difficult to unambiguously identify neurite processes. F. Example of a culture that has been subjected to Percoll density centrifugation to enrich for neurons. Note the individual neurons with processes are easily identifiable, as are neurons with no growth. Neurons were plated on laminin in defined medium in the absence of added trophic factors. Scale bar - A, D-F-100 $\mu \mathrm{m} ; \mathrm{B}, C-500 \mu \mathrm{m}$.
(Figure 3B). ${ }^{58}$ Sensory ganglia are removed from the animal, the dorsal and peripheral roots are usually trimmed off and the ganglion is either sectioned into smaller pieces or plated whole. In order to facilitate attachment, the use of collagen gels or Matrigel has been employed. Following attachment, various trophic factors can then be added to the medium and outgrowth assessed either directly (using phase contrast microscopy optics) or after fixation and immunostaining with different markers. The advantage of this system is the relative ease of preparation and measurement of outgrowth, which tends to be fairly linear if the plating is done on a two-dimensional surface. The use of collagen or ECM gels results in a 3-D growth environment and outgrowth can be more difficult to measure with phase contrast (see Figure 3C). There are some disadvantages with this model, including the inability to determine the identity or the proportion of cells giving rise to any outgrowth observed. In addition, there can often be significant cell death within the explants due to lack of access to nutrients or gas exchange.

The most common model is the culture of dissociated neurons (Figure 3D-F). Here the ganglia are removed from the animal and subjected to different enzymatic treatments followed by centrifugation to remove unwanted debris ${ }^{59}$ Dissociated neurons are then plated onto culture surfaces coated with various substrates, including poly-lysine, poly-ornithine, collagen, fibronectin, laminin or a combination of these. Such culture protocols often result in mixed neuron-glial cultures (see Figure $3 \mathrm{E}$ ), which may confound the interpretation of the effects of individual medium components such as neurotrophins, ECM molecules etc. In order to minimize such non-neuronal contamination, investigators have employed differential centrifugation through various gradients or isolation of specific neuronal populations using cell surface markers (eg., percoll, bovine serum albumen, magnetic beads ${ }^{60}$ ). With such protocols, relatively pure neuronal cultures can be obtained with no obvious alterations in the overall neuronal population makeup (Figure 3D, F). Alternatively, a preplating step can be employed, which relies on the selective adhesion of the non-neuronal cells to tissue culture plastic; after one-two hours of incubation, the non-adherent cells (mainly neurons) can be gently removed and pelleted for replating on the appropriate substrates. While these cultures are more time consuming to prepare than the explants, the advantage is that one has a relatively pure population of neurons, where individual cells and their potentially unique responses to experimental conditions can be readily assessed. Use of immunostaining for different markers or combinations of markers (such as those noted above) allows for the distinction between the different types of cells and how they might respond differentially to experimental interventions. Dissociated cultures can be plated in small volumes (ie., on coverslips or chambered slides), in order to asses individual cellular responses, or in larger volumes (eg., multi-well culture dishes) for larger scale biochemical analyses.

A third in vitro model that has been employed involves the use of a pre-conditioning peripheral nerve lesion. ${ }^{61}$ Usually the sciatic nerve is damaged (either by crush or cut) and the animal is allowed to recover for one to several days prior to removal of the lumbar ganglia and preparation for culture. The rationale for this model is that the injury step provides some sort of 'priming' that results in robust growth from certain neurons when the cells are dissociated and placed in vitro.$^{62}$ Proponents suggest that this 
is more reminiscent of what happens in vivo following a peripheral nerve injury, where Wallerian degeneration and the cell body reaction proceed, along with the local environmental changes that can occur. ${ }^{7}$ However, one might argue that any events that one might wish to examine directly as having an influence on axonal growth have already occurred well in advance of the cells being placed in culture. In comparison to the prelesion model, neurons removed from naïve animals most certainly undergo damage/axotomy and also are quite capable of similar robust growth responses.

An additional factor that should be considered is whether results obtained with embryonic neurons can be considered comparable to those obtained with mature or adult DRG cultures. Embryonic neurons isolated from mouse models where the neurotrophin requirement for survival has been overcome by deletion of the apoptotic protein $\mathrm{Bax}^{63}$ tend to display a fairly simple, essentially bipolar form of growth; in addition, because of the developmental stage of the cells at the time of isolation, the typical phenotypic differentiation of the cells has not been

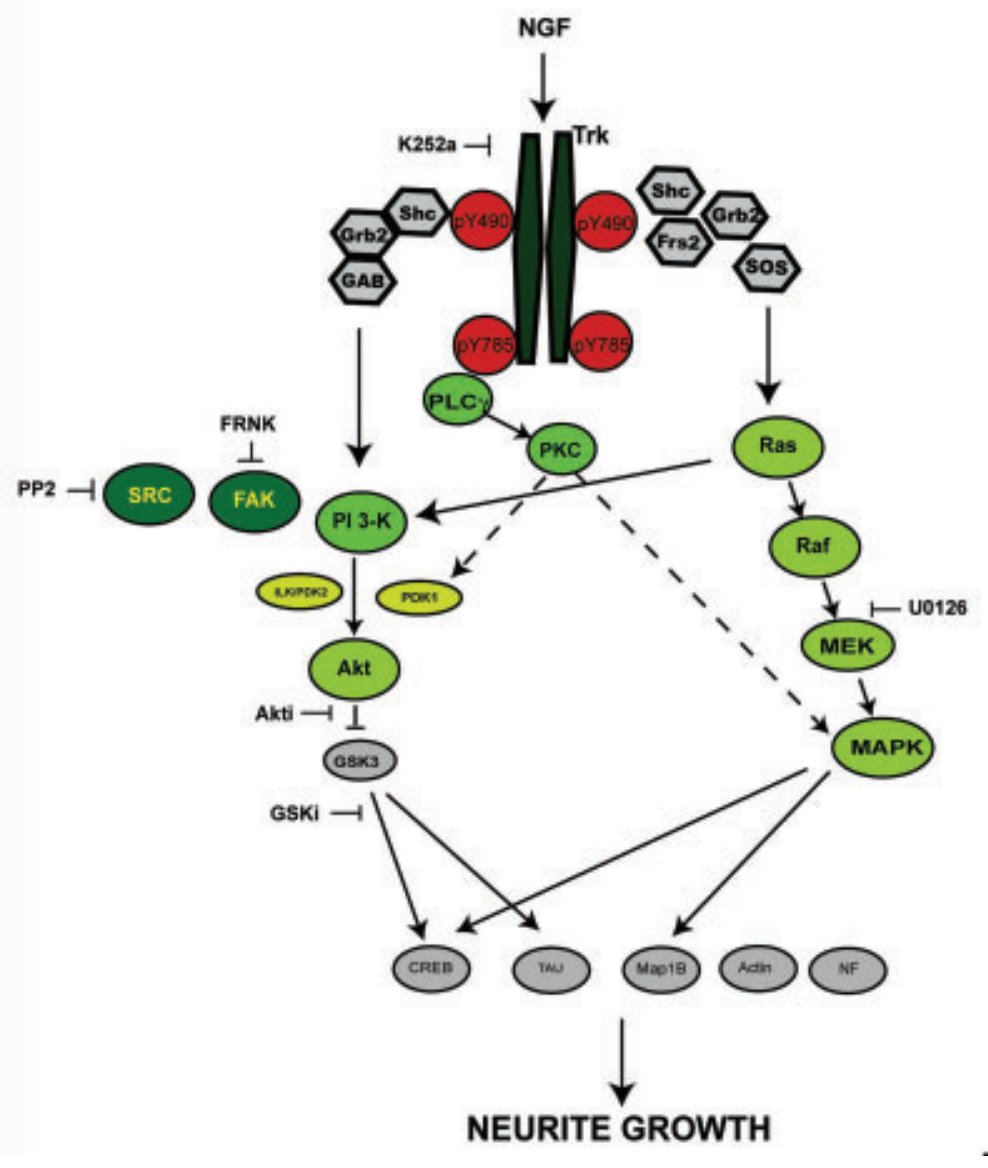

Figure 4: Neurotrophin signaling. Activation of the Trk receptor by NGF controls three major signaling pathways: the Ras-MAPK pathway, the PI 3-K-Akt pathway and PLC $\gamma$ pathway. The contributions of the Ras-MAPK, PLC, PI 3-K pathways to neuritogenesis have been demonstrated in a variety of neuronal cell lines and primary neurons, although the relative requirement for the different cascades varies in different cells. See text for details. fully realized. In contrast, cultures of postnatal and mature DRG neurons are more heterogeneous in their makeup and the neurons display rather more complex forms of neurite growth, with some neurons having quite elaborate branching patterns and others showing less branching and more elongated neurite growth.

The final component for consideration in in vitro models (and one that might account for the variety of observations made by different groups) relates to the culture medium. Adult DRG neurons do not required exogenous neurotrophins for their survival in vitro, as supported by a large body of experimental data beginning with the observation made by Lindsay and colleagues some 20 years ago. ${ }^{64}$ For example, mature DRG neurons plated on poly-lysine coated surfaces in a defined culture medium (such as DMEM or Neurobasal with serum-free supplements) survive quite well for at least 72-96 hours in our experience, based upon cell survival assays and observations that subsequent addition of NGF, GDNF, or laminin to these cells results in neurite growth. ${ }^{35,65,66}$ However, like most primary cell culture systems that rely on mechanical or enzymatic dissociation, there is some initial cell death likely due to the isolation procedures themselves.

In all these model systems, in order to determine the involvement or necessity of a given signaling intermediate, the general experimental approach has been to somehow activate, inhibit or knock out the individual components, using for example pharmacological agents, overexpression of dominant-inhibitory or active cDNA constructs, small interfering RNA (RNAi). A potential limitation with all such studies is whether the agent employed is specific (or highly selective) in its actions or whether there might be non-specific effects that could have an impact on a comprehensive understanding of signaling networks.

\subsection{Trophic factors and axonal growth or regeneration}

Neurotrophins and other growth factors have been shown to have trophic influences on mature peripheral sensory neurons..$^{4,7,67,68}$ In addition to NGF and GDNF, factors of particular interest in terms of influencing DRG axonal growth include IGF-1 (and insulin itself), ${ }^{69-73}$ FGF, ${ }^{74-76}$ VEGF, ${ }^{77}$ factors acting via the EGF receptor (though not EGF itself $^{71}$ ) such as amphiregulin ${ }^{78}$ and TGF-b. ${ }^{79}$

Interestingly, in dissociated cultures of mature DRG neurons, neither BDNF nor NT3 displayed much influence on growth. ${ }^{32,44,75,80}$ In experiments where adult DRG neurons were cultured in Campenot compartment cultures, only NGF was able to promote neurite growth into the axonal compartment, while BDNF had either no effect or an inhibitory influence. ${ }^{44,81}$

\subsection{Cellular signaling required for neurite growth}

We know that neurotrophins (and related growth factors) elicit neurite growth, and a number of neurotrophin (NT)-dependent signaling 
pathways have been described (see Figure 4). ${ }^{52,82-85}$ The contributions of the Ras-MAPK, PLC $\gamma$, PI 3-K pathways to neuritogenesis have been demonstrated in a variety of neuronal cell lines and primary neurons, although the relative requirement for the different cascades varies in different cells and is also a function of the developmental age. ${ }^{83,86-91}$

Cultures of mature DRG neurons have been employed to determine the relative contributions of the different signaling arms to neurite growth (initiation, elongation and branching) in the absence of effects on neuronal survival. Some of the differences observed in the contribution of signaling pathways (as will be discussed below) can be attributed to the use of the different culture models noted above in section 2.2 , as well as to the manner in which growth has been assessed.

Inhibition of PI 3-K has been shown to block outgrowth in all models examined. Thus, NGF- and NT3-evoked outgrowth from adult mouse DRG explants are attenuated in the presence of PI 3-K inhibition using LY29004. ${ }^{88,91,92}$ The p1108 isoform of PI 3$\mathrm{K}$ has recently been reported to be a key component for outgrowth. ${ }^{93}$ NGF-induced neurite growth from dissociated DRG neurons cultures from adult Bax knockout mice, ${ }^{89}$ and NGF, IGF and GDNF evoked growth from adult rat DRG neurons ${ }^{35,70,71,94}$ also show a requirement for activation of the PI 3-K pathway. Signaling via this pathway has been shown to require the downstream activation of Akt and inhibition of GSK3. Direct inhibition of Akt with a selective pharmacological inhibitor or RNAi, induces a similar degree of growth inhibition as does blockade of PI 3-K..$^{35,94,95}$ While such inhibition also blocks the inhibition of GSK3, use of $\mathrm{LiCl}$ to inhibit GSK activity also results in a similar outcome. ${ }^{70}$ It should be noted, that while PI $3-\mathrm{K}$ is generally considered to be essential for survival in most cells, the concentrations of the inhibitors used to attenuate PI 3-K signaling or its downstream effectors (GSK3 inhibitors, Akt inhibitors, Akt siRNA) have been reported to have no significant effect on neuronal survival of these adult sensory neurons, suggesting redundant pathways acting to promote survival.

With respect to a requirement for MEK and MAPK activation, the situation is not as straightforward. Inhibition of MAPK activity using PD98059 blocks NGF- and GDNF-, but not NT3-, evoked outgrowth from adult mouse DRG explants. ${ }^{91}$ Other studies report no effect of MAPK on neurite growth..$^{71,96}$ In contrast to the effects we have observed on NGF-dependent growth, we find that MAPK inhibition blocks GDNF- and IGFdependent neurite growth in adult DRG neurons. ${ }^{35,70}$

Contrary to the inhibitory effects observed in some investigations, positive effects on growth have also been reported. Thus, Wiklund and colleagues reported that MEK or MAPK inhibition enhanced NT3-dependent growth from DRG explants. ${ }^{91}$ We have also observed similar effects with NGFevoked outgrowth from dissociated neurons, where total growth and the amount of neurite branching was increased in the presence of U0126; we attributed this enhancement of growth to the increase in pAkt observed in the neurons when MAPK was inhibited. ${ }^{35,70,94}$

Interestingly, the enhanced spontaneous growth that results from conditioning lesions ${ }^{61}$ appears not to require either NTdependent signaling nor the PI3-K or MAPK signaling pathways. ${ }^{89,92}$
How these pathways actually regulate neuritogenesis is not completely known. Downstream events must eventually result in alterations to the neuronal cytoskeleton in order to link extracellularly-mediated signaling events with the physical protrusion and extension of neuritic processes. Furthermore, signaling pathways can ultimately have an effect on gene transcription required for growth and there are an increasing number of studies implicating the need for specific transcription factors in growth and regeneration (eg., $\left.{ }^{67,97-99}\right)$.

\section{Extracellular matrix and axonal growth}

The ability of a neuron to extend a process over a biological substrate requires there to be a direct interaction with the extracellular matrix or basal lamina. The ECM of the PNS is generally composed of several classes of macromolecules including the proteoglycans such as heparan sulfate proteoglycan and the chondroitin sulfate proteoglycans, and the structural components like collagen, as well as laminin and fibronectin. ${ }^{100-104}$

\subsection{Laminin supports axonal growth}

In the PNS, laminin is the major component of the ECM that not only influences axonal growth and regeneration, but also plays a role in the regulation of Schwann cell migration, proliferation and myelination.

Laminin initially isolated from basement membranes produced by mouse tumor Engelbreth-Holm-Swarm or EHS cells, is a large trimeric protein with $\alpha, \beta$ and $\gamma$ subunits that bind together to form a cross-like structure which serves specific cellular functions, such as attachment, migration, neurite growth and axonal elongation. ${ }^{105}$ At least 15 different laminin isoforms have been identified, which are expressed in various regions of the mammalian body and by different cell types. These isoforms vary only by their expression of $\alpha, \beta$ and $\gamma$ subunits, and have been termed laminin- 1 to laminin-15. ${ }^{105,106}$ In the PNS, laminin is synthesized and secreted by a variety of cell types, although Schwann cells are the major producer of laminin. ${ }^{107}$ Laminin-2 (composed of $\alpha 2, \beta 1$ and $\gamma 1$ chains) is a major component of the PNS, ${ }^{100}$ although interestingly it is laminin-1 that has been used most effectively in promoting axonal growth in vitro. ${ }^{108,109}$ Laminin plays an important role in axonal regeneration in vivo and in neurite growth in vitro (see $\left.{ }^{67,105,106}\right)$.

While numerous studies have shown that laminin supports axonal growth from DRG sensory neurons in vitro (eg., ${ }^{35,109-115}$ ), it appears that not all classes of DRG neurons respond equivalently to laminin. ${ }^{35,115}$ Other ECM molecules like collagen or fibronectin are less effective in promoting outgrowth from mature sensory neurons. ${ }^{94,109,116,117}$

\subsection{Neuronal receptors for ECM molecules}

In general, cells interact with ECM molecules such as collagen, laminin or fibronectin using the integrin receptors. ${ }^{118}$ Integrins, abundant on the leading edge of growth cone peripheral domains and migrating cells, are a class of heterodimeric transmembrane receptors that are composed of $\alpha$ and $\beta$ subunits, the cytoplasmic tails of which are short and have no intrinsic enzymatic activity. ${ }^{119}$ To date, $18 \alpha$ and $8 \beta$ mammalian subunits have been identified and different combinations of these subunits allow for the creation of at least 
24 different integrin receptors. ${ }^{120}$ Each of these receptors have been shown to bind different ECM molecules with partial overlap between ligands, and most integrins recognize more than one ECM molecule. ${ }^{119,121,122}$ For example, $\alpha 1 \beta 1$ binds both laminin and collagen, but laminin also acts as a ligand for $\alpha 2 \beta 1$, $\alpha 3 \beta 1, \alpha 6 \beta 1, \alpha 6 \beta 4$ and $\alpha 7 \beta 1 .{ }^{123-125}$ Much of the work studying integrin receptors has focused on their role in cell migration, angiogenesis, wound healing and metastasis. ${ }^{126-129}$ However, the importance of these receptors in growth and repair of PNS neurons has also been identified..$^{3,123}$

\subsection{Integrins and sensory neurons}

Adult DRG neurons and their axons express integrins that allow for interaction with ECM and basal lamina molecules like laminin, collagen and fibronectin. However, the level of expression of these receptors in the adult appears to be less than that of developing neurons and this is reflected by the relatively reduced neurite growth observed with mature neurons compared to neonatal cells. ${ }^{130}$ For instance, forced expression of the $\alpha 1$ integrin in adult sensory neurons resulted in outgrowth comparable to that of developing sensory nerves. ${ }^{130}$ Although the $\beta 1$ subunit is expressed by most, if not all cells within the adult DRG, variability in neuronal populations with respect to the alpha subunits, $\alpha 1, \alpha 3, \alpha 5, \alpha 6$ and $\alpha 7$ have been reported..$^{94,108,131-134}$ Of interest, are the observations that the cutaneous afferents during development tend to show more $\alpha 7 \beta 1$ expression than proprioceptive afferent, ${ }^{134}$ and that IB4+ve neurons appear to express little if any $\alpha 7 \beta 1$ integrin. ${ }^{132}$

However, there do appear to be population differences in the ability of mature DRG neurons to respond to the substrates, which is likely linked to their expression of the different integrin subunits. For example, similar to the significant growth observed from adult DRG explants in Matrigel in the absence of added trophic factors, ${ }^{58,109}$ we have shown that dissociated DRG neurons plated on laminin in the absence of added growth factors elaborate significantly more neurite growth than cells plated on poly-D-lysine alone ${ }^{94}$ (Figure 5). This difference was not attributable to differences in cell adhesion and was directly related to the biological effects of laminin binding. ${ }^{94}$ Although these results suggested that laminin binding alone was sufficient to stimulate significant neurite growth in the absence of added growth factors, we observed that not all neurons responded equally. ${ }^{35}$ As noted above, the DRG is made up of a heterogeneous population of cells that can be classified crudely based on cell body diameter, and more specifically, upon their ability to bind the lectin IB4 (predominantly non-peptidergic small diameter neurons), express the peptide CGRP (small and medium diameter neurons) or express the heavy chain neurofilament NF200 (predominantly medium and large diameter neurons). ${ }^{30,33}$ Observations made at 24 hours after plating suggested that the small diameter DRG neurons were unresponsive to laminin, and only medium and large diameter neurons were able to extend neurites (Figure 6A). However, by 48 hours, the CGRP+ve small neurons also responded with extensive neurite growth (Figure 6C). More interestingly, we noted that the IB4+ve cell population was not at all responsive to laminin (or other ECM substrates) in the absence of added growth factors (Figure 6D); neurite growth was only observed if GDNF was subsequently added (Figure 7). ${ }^{35}$ A recent report confirms our observations, noting that there is little spontaneous growth from IB4+ve neurons on laminin or collagen compared to the non-IB4 expressing neurons. ${ }^{135}$

As with laminin, integrin receptors have also been shown to be upregulated after injury to PNS neurons. For example, upon injury of the peripheral processes of the DRG, expression of the laminin-associated integrin receptors $\alpha 6 \beta 1$ and $\alpha 7 \beta 1$ is increased, and this has been suggested to play an important role in regeneration after PNS injury. ${ }^{136}$ Similarly it has been shown that DRG neurons receiving a preconditioning lesion prior to severe injury have significantly better regeneration in the presence of laminin than neurons that did not receive a preconditioning lesion. This effect was suggested to be due to an upregulation of the $\alpha 7 \beta 1$ integrin receptor after the initial injury, since inhibition of this receptor was shown to inhibit the preconditioning growth effect. ${ }^{108}$ However, recent results that indicate that forced overexpression of $\alpha 7$ integrin in DRG neurons (both IB4+ve and IB4-ve cells) failed to promote axonal growth in vitro. ${ }^{135}$ Preconditioning lesions also enhance the responsiveness of adult DRG neurons to fibronectin, via upregulation of the $\alpha 5$ integrin. ${ }^{117}$

\subsection{Integrin signaling}

Although integrins have short cytoplasmic tails with no intrinsic enzymatic activity, they have been shown to function by
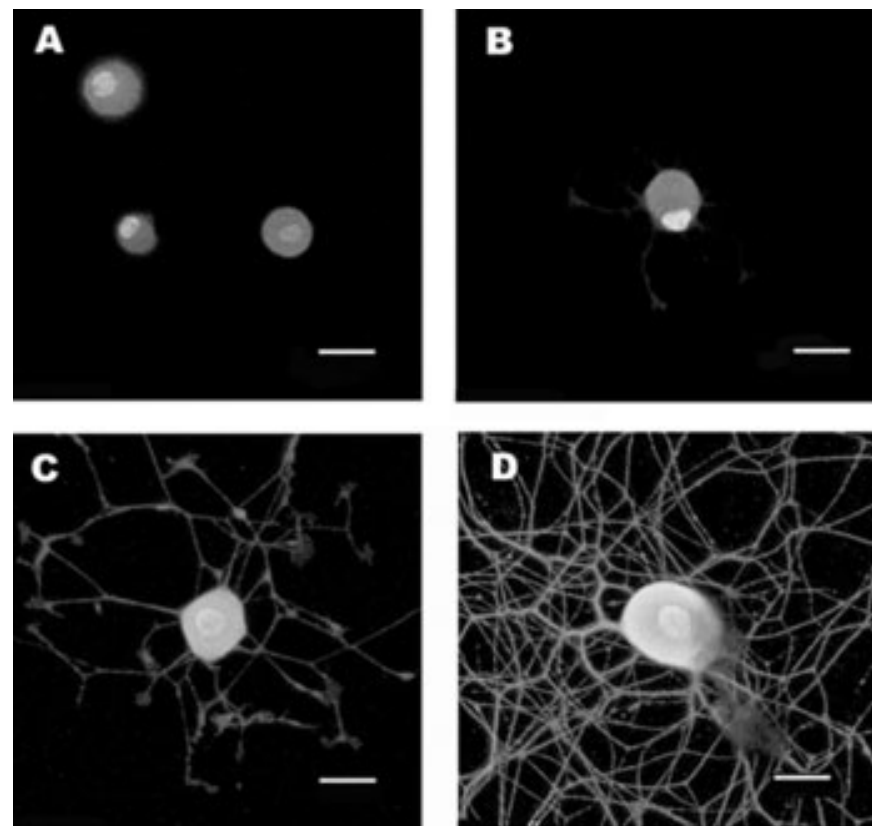

Figure 5: Comparison of the influence of substrate and neurotrophic factor on neurite growth from adult rat DRG neurons. DRG neurons were dissociated and plated on either polylysine $(A, B)$ or laminin $(C, D)$ coated substrates in the absence $(A, C)$ or presence $(B, D)$ of $N G F$. In this example, neurons were fixed at $24 \mathrm{hrs}$ and immunostained with an anti-FAK (focal adhesion kinase) antibody. Note the increased neurite growth from the cell plated on laminin alone $(C)$ and a further enhancement with added NGF (D). Scale bar - $20 \mu \mathrm{m}$. 

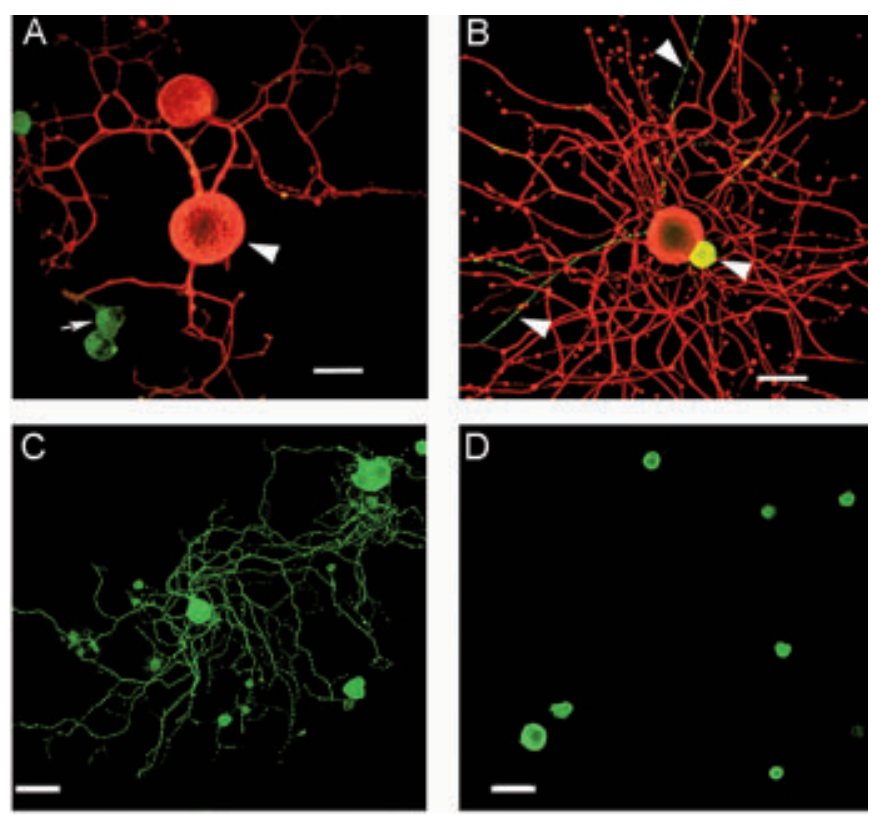

Figure 6: Differential response of neurons to substrate. (A-B) Neurons were plated on laminin-coated substrates and cultured in the presence or absence of NGF $(A$, no NGF; $B,+N G F)$. At 24 hrs cultures were fixed and immunostained for CGRP (green) and NF200 (red). (A) Laminininduced growth is most extensive in NF200+ve DRG neurons (red neuron, arrowhead), and this is enhanced in the presence of $N G F(B$, red). CGRP+ve neurons (green) show little growth on laminin alone ( $A$, arrow); plating them in the presence of NGF did stimulate increased neurite growth (B, green cell and arrowheads). (C-D) Neurite growth from $N G F$-responsive $(C)$ and $G D N F$-responsive $(D)$ neurons plated on laminin with no growth factors for $48 \mathrm{hrs}$. (C) CGRP+ve neurons show increased growth compared to $24 \mathrm{hr}$ cultures. (D) GNDF-responsive neurons were separated from NGF-responsive neurons using IB4labelled magnetic beads, and IB4+ve cells shown in $(D)$ do not exhibit any growth. Scale bar - $50 \mu \mathrm{m}$. (adapted from figures originally published in ${ }^{35}$ ).

signaling across the membrane in two distinct directions"inside-out" and "outside-in". "Inside-out" signaling is where molecular intermediates within the cell act to alter receptor affinity and activation state by altering the conformation of integrin cytoplasmic tails. ${ }^{137}$ Although this type of signaling is of interest, the intent of this review is to provide the current knowledge on induction of PNS regeneration via the provision of extracellular molecules. Thus, we will focus our discussion on the second type of integrin signaling, "outside-in". During "outside-in" signaling, ligands such as laminin activate integrins by binding to the extracellular component of the receptor and stimulating a conformational change in the cytoplasmic tail. ${ }^{119,121,138-140}$ Coupled with ligand-induced integrin clustering, these events promote the formation of aggregates at the cell surface called focal adhesions. ${ }^{119,121}$ Subsequently, this results in the recruitment of adaptor proteins such as talin and vinculin, which act to link integrins to the actin cytoskeleton and in turn, stimulate the recruitment of a number of different cytoplasmic protein kinases. The kinases associated with these focal adhesions include focal adhesion kinase (FAK), integrin-linked kinase (ILK) and the Src-family kinases (such as Src, Fyn, and Yes). ${ }^{120,141-147}$ Activation of these early integrin-linked intermediates has also been suggested to activate the downstream signaling components Ras, MAPK and PI 3-K, all of which have been shown to be associated with neurotrophindependent responses as we have noted. Figure 8 illustrates potential intermediates involved in ECM-integrin activation and downstream signaling that could contribute to axonal growth.

\section{Synergism between neurotrophin and integrin induced signaling pathways}

While many examples of physical association between integrin and growth factor receptors, including insulin-like growth factor-1 receptor, platelet-derived growth factor receptor, and epithelial growth factor receptor, have been identified, ${ }^{148}$ to date there have been no reports of direct interactions between integrins and neurotrophin receptors (either the Trks or p75). As a limited number of molecular signaling intermediates exist within a cell, it is not surprising to find that crosstalk between neurotrophin and integrin activated signaling cascades occurs. Despite the fact that there is ample evidence of a requirement for both neurotrophic factors and a permissive environment for peripheral nerve regeneration in vivo, as well as promoting axonal growth in vitro (almost all in vitro studies employ ECMcoated substrates), there have been few studies that directly
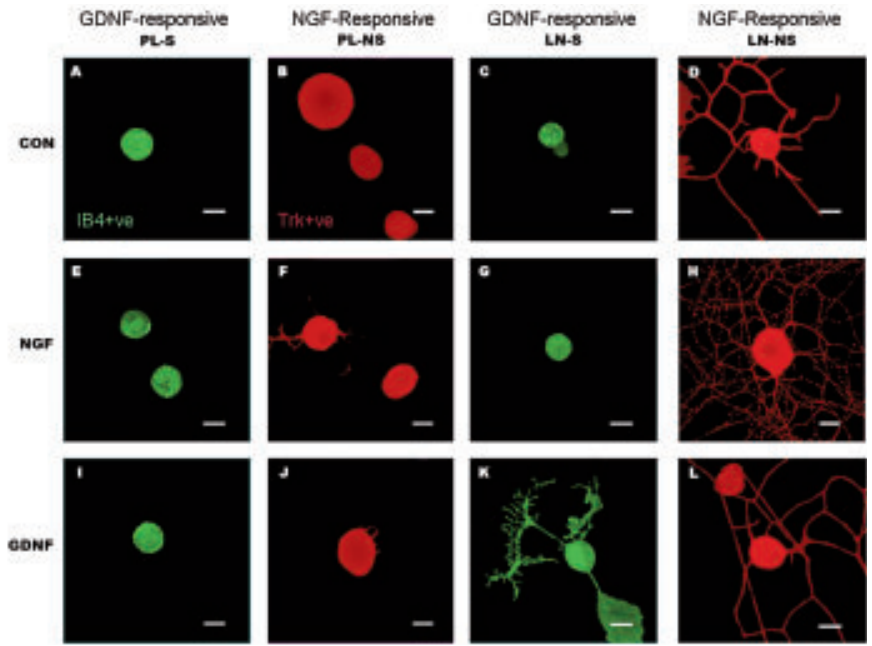

Figure 7: IB4+ve DRG neurons require GDNF for neurite growth regardless of the presence of a permissive substrate. GDNF-responsive neurons (IB4+ve, green, S) and NGF-responsive neurons (Trk+ve, red, $N S)$ were isolated as outlined in.$^{60}$ Neurons were plated on poly-lysine $(P L)$ or laminin $(L N)$ in the presence or absence of GDNF or NGF. $I B 4+$ ve cells do not show any significant neurite growth on PL (A) or $L N$ $(C)$, nor is there any stimulation of growth with $N G F(E$ and $G)$. However, GDNF does elicit growth from these IB4+ve cells when plated on $L N(K)$. In contrast, $N G F$-responsive cells show significant neurite growth on $L N(D)$ which is potentiated by the addition of $N G F(H)$. These cells were not responsive to GDNF $(L)$. Scale bar - $50 \mu \mathrm{m}$ (reproduced from ${ }^{35}$ ). 


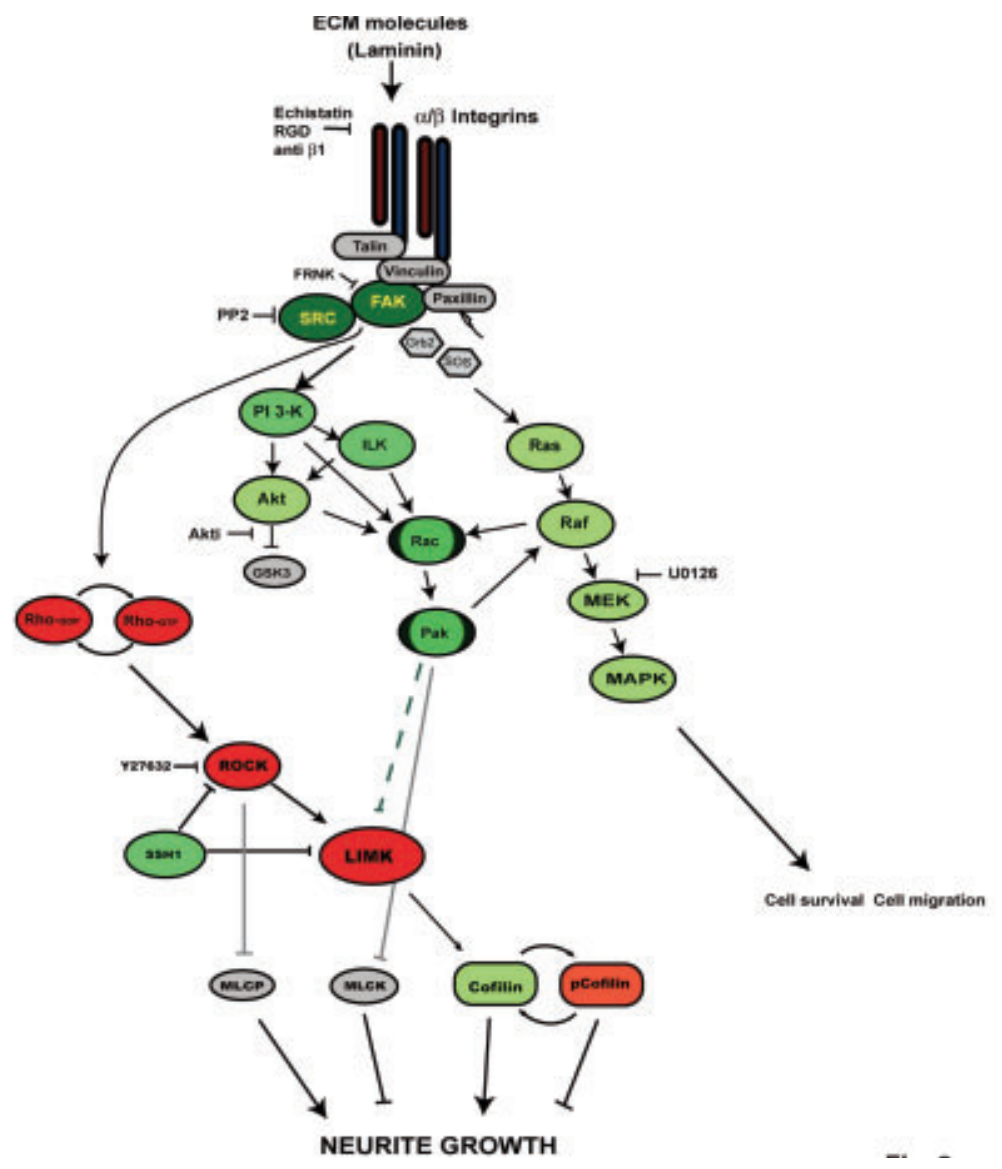

Figure 8: Integrin signaling. Simplified schematic illustrating known signaling pathways activated following ligand binding and integrin clustering. See text for details.

inhibitory constructs. ${ }^{35,94,95}$ We had previously shown that the NGF-responsive cell population (NF200+ve and CGRP+ve) responds to laminin with increased neurite growth in the absence of added trophic factors, and that neurite growth is potentiated by the addition of NGF (Figure 5). ${ }^{35}$ The signaling intermediates Src, Fyn, ILK, and FAK, are common components to various cell adhesion and growth factor receptors, thus, we examined the possibility that one of these components could provide the essential link between NGF- and laminin-induced axonal regeneration in adult DRG neurons.

We identified $\mathrm{Src}$ as a collaborative component upstream of PI 3-K/Akt signaling, activated by both NGF and laminin, which leads to stimulation of optimal levels of neurite growth from adult NGF-responsive DRG neurons. ${ }^{35}$ In our initial studies, NGF- and laminin-induced neurite growth were assessed 24 hours after plating, but in the course of those experiments it became evident that extensive neurite growth was occurring at much earlier time points. ${ }^{35,94}$ Thus, to determine the critical points of collaboration between NGF and laminin induced signaling a time course of early signaling intermediate activation was undertaken. ${ }^{95}$ If $\mathrm{Src}$ is the critical point of collaboration between NGF and integrin activated signaling in these cells, it should be activated at early time points by both NGF and LN and inhibition of Src should lead to the interruption of neurite growth via alteration of downstream targets. Adult NGF-responsive DRG were neurons stimulated with $\mathrm{NGF}, \mathrm{LN}$, and $\mathrm{LN}$ plus NGF (LN+NGF) for ten minutes, one hour, or six hours and subsequently analysed. Significant neurite growth was observed primarily at the six

examine such interactions and related signaling in mature neurons.

\subsection{Experimental studies elucidating convergence of signaling pathways}

Based upon our own observations (as well as those of others) of the enhancement of neurite growth when a permissive environment (eg., laminin substrate) is coupled with the provision of neurotrophic factors (such as NGF or GDNF), we undertook a series of studies to directly examine signaling pathways activated by integrin-dependent and neurotrophindependent signaling events..$^{35,60,94,95}$

In these studies, mature DRG neurons were plated on polylysine (PL, a non-activating substrate) or laminin (LN, integrinactivating) and then treated with NGF, and assessed at 24 hours after plating. In addition, we evaluated earlier signaling events using cells plated on PL and subsequently stimulated with NGF or LN in solution. Neurite growth was analyzed in each of the conditions (PL control, NGF, LN and NGF+LN) using confocal microscopy, and activation of signaling intermediates was determined using Western blotting. The requirement for signaling pathways was determined using either pharmacological inhibition, RNAi knockdown or overexpression of hour time point, while activation of signaling intermediates was detectable at the earliest time point analyzed (ten minutes post stimulation) with temporal and quantitative differences in intermediate activation by the different stimulation treatments (Figure 9). Furthermore, neurite growth was blocked by inhibition of Src, FAK, and PI 3-K, while MAPK inhibition was without significant effect. ${ }^{95}$

The key findings were that the inhibition of Src and FAK resulted in inhibition of Akt and MAPK.${ }^{95}$ These results, paired with the facts that Akt and MAPK are known intermediates in both NGF-induced Trk signaling $70,94,149-154$ and LN-induced integrin signaling, ${ }^{94,150,155-157}$ indicate that both Akt and MAPK are located downstream of Src and FAK. Src is activated initially and subsequently activates FAK, likely forming a signaling complex that stimulates the activation of both Akt and MAPK signaling pathways. ${ }^{95}$ Src-FAK signaling complexes have been previously reported to form after integrin ligation and to be translocated to focal adhesions, where they can activate downstream signaling cascades. ${ }^{158-160}$

Although our results indicate that PI $3-\mathrm{K}$ is located downstream of Src and FAK, it still influences both $\mathrm{Src}$ and FAK signaling, likely by way of a negative feedback system. For instance, inhibition of Src and FAK inhibits PI 3-K activation, 


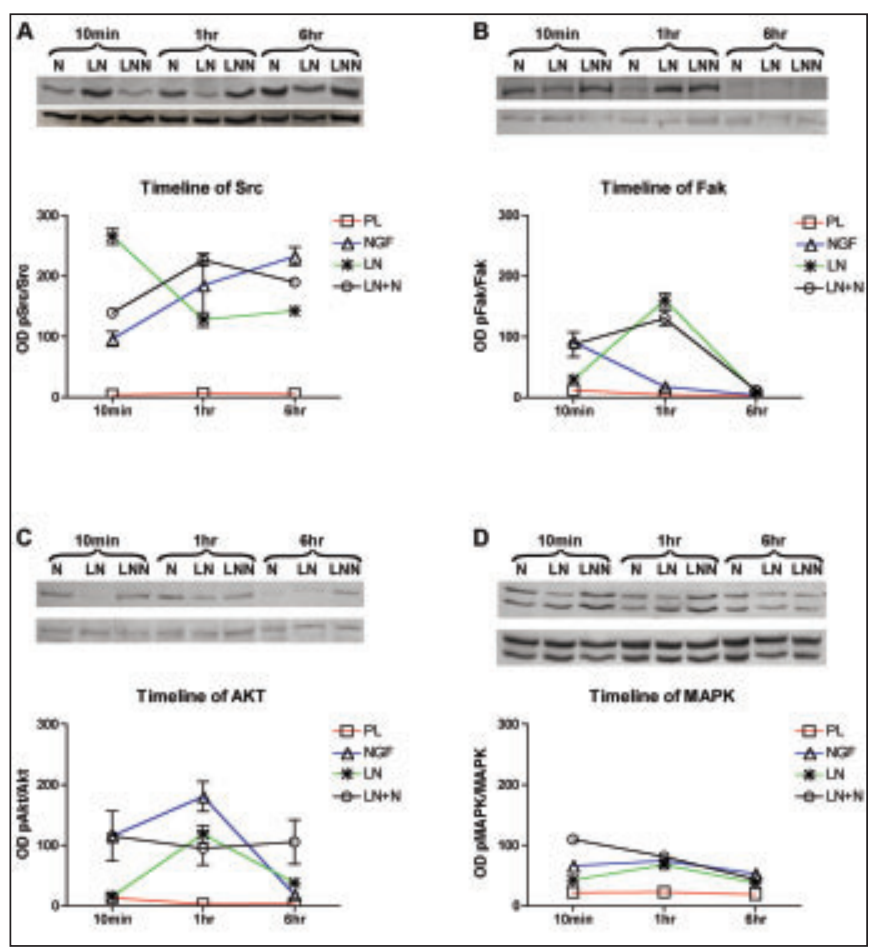

Figure 9: Signaling intermediates are activated in ligand- and temporally- dependent manner. DRG neurons were plated on PL and subsequently treated with $N G F, L N$ or $L N+N G F$ for $10 \mathrm{~min}, 1 \mathrm{hr}$ or $6 \mathrm{hrs}$, followed by Western blotting of lysates. Each graph represents a single intermediate, and each line of the graph represents the timeline of activation in reponse to the specifc treatments. A-D: Western blot and corresponding timeline of activation of early signaling intermediates Src (A), FAK (B), Akt (C) and MAPK (D). The top panel of the Western blots presents the phospho-specific proteins (eg., pSrc, representative of activation) and the bottom panel shows the corresponding total protein (eg., Src). (reproduced from ${ }^{95}$ ).

and inhibition of PI 3-K also attenuates both Src and FAK activity. ${ }^{94,95}$ However, we still suggest that PI $3-\mathrm{K}$ is located downstream of Src and FAK and not a part of the above mentioned signaling complex, because inhibition of this intermediate does not effect the activity of MAPK, suggesting that the PI 3-K/Akt signaling pathway is completely separate from the MEK/MAPK signaling pathway. Knockdown of Akt or inhibition of Akt downstream from PI 3-K also resulted in decreased total neurite growth and branching, suggesting that while Akt is important in the growth process, the actions of PI 3$\mathrm{K}$ on the other signaling intermediates are also required..$^{35,95}$

While Src and FAK are key points of collaboration between integrin and neurotrophin signaling in the DRG neurons, this is not the only possible point of integrin and growth factor crosstalk. For instance, ILK was identified as being a necessary component of NGF-induced neurite outgrowth in embryonic chick DRG neurons. ${ }^{150}$ In these experiments, it was shown that Akt was directly phosphorylated by ILK, and the presence of a dominant negative ILK construct attenuated Akt-induced neurite growth, suggesting that ILK in an important component of the PI 3-K/Akt signaling pathway, and potentially located downstream of Src. The potential role of ILK in adult neurons remains to be investigated.

In summary, our work shows that LN- and NGF-induced neurite growth in adult NGF-responsive DRG neurons is dependent on early activation of the PI-3K/Akt signaling pathway rather than the MEK/MAPK pathway. Crosstalk between integrin- and Trk-activated signaling occurs at the level of Src and FAK upstream of PI-3K/AKT and MEK/MAPK signaling pathways (Figure 11). We attribute the enhanced growth induced by the simultaneous treatment with laminin and NGF to the sustained activation of Src and the downstream signaling intermediate Akt. ${ }^{94,95}$

One final example of the role of the substrate on promoting or modulating growth from adult DRG neurons is shown in Figure

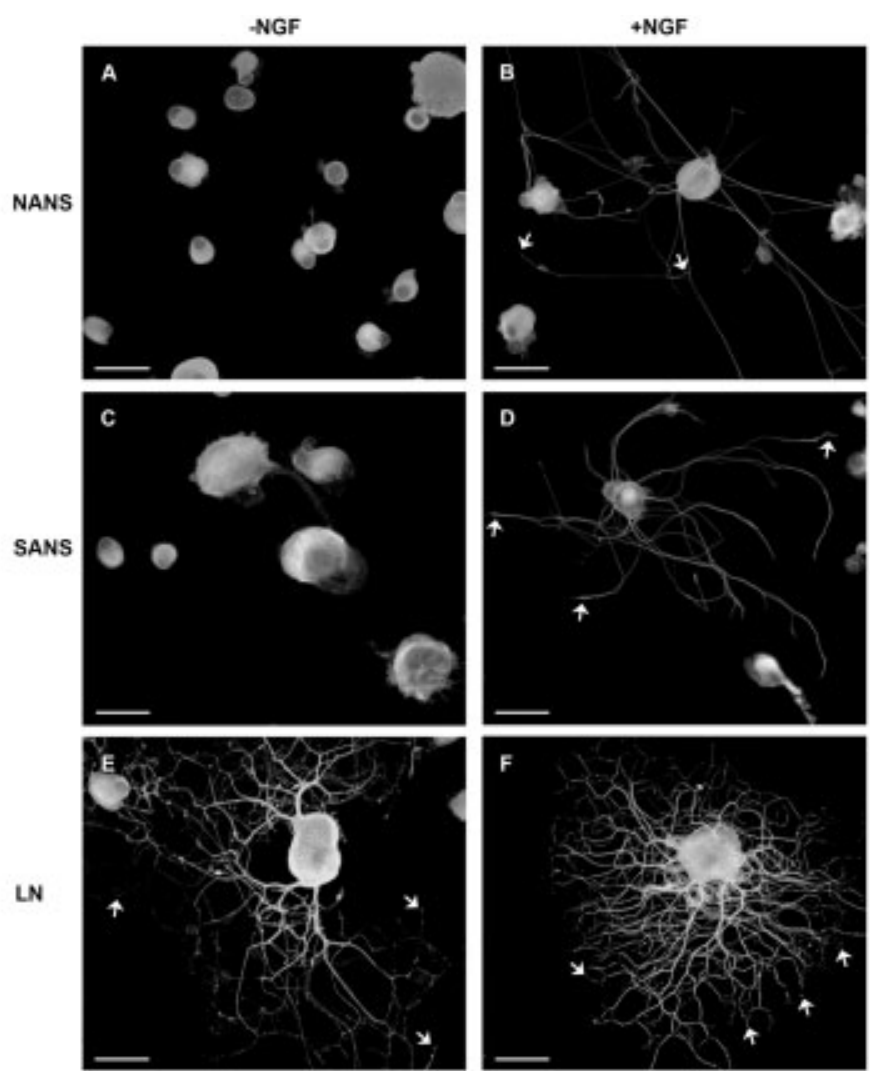

Figure 10: Neurite growth from adult DRG neurons plated on synthetic nanofibrillar (UltraWebTM) cell growth surfaces. Cells were plated on coverslips with untreated (NANS), polyamine treated (SANS) or laminincoated (LN) SANS nanofibres plus or minus NGF for $24 \mathrm{hrs}$ prior to fixation and immunostaining with antibodies directed against $\beta 1$ integrin and total tubulin (merged channel images). No significant amount of growth was observed for cells plated on the NANS (A) or SANS $(C)$ in the absence of NGF. However, when NGF was added there was increased growth $(B, D)$. As in the 2-D cultures, the presence of $L N$ resulted in enhanced outgrowth $(E)$, which was further potentiated when $N G F$ was added $(F)$. Arrows point to local accumulation of integrin in the growth cones. Scale bar - $50 \mu \mathrm{m}$. 
10. Here, neurons were plated on coverslips coated with a synthetic $3-\mathrm{D}$ fibrillar matrix (approximately 10-20 $\mu \mathrm{m}$ in depth, UltraWebTM, Donaldson Corporation) in the presence or absence of NGF. Neither the non-modified surfaces (NANs, Figure 10A-B) nor the polyaminemodified surfaces (SANs, Figure 10CD) were unable to support any growth in the absence of NGF. Further modification of the SANs-treated coverslips with LN elicited extensive growth (Figure 10E) that was, as expected, further modified by the addition of NGF (Figure 10F). What is not so obvious from these photographs is the fact that the neurites grew along and penetrated the web-like matrix.

Signaling pathways activated by NTFs and by ECM molecules like laminin interact in complex ways that lead to promotion of neurite growth from mature DRG neurons. Figure 11 presents a summary signaling diagram that illustrates potential interactions, and also notes some of the downstream effectors that could regulate cytoskeletal events necessary for axonal growth. Although we have not addressed them, other environmental components that may act to inhibit growth or to act as guidance cues in the mature nervous system will also clearly influence growth or regeneration in the mature $\mathrm{PNS}$.

\section{Coordinating ligand induced signaling and cytoskeletal events required for axonal growth}

In order for signaling via the NTs and/or integrins to result in the physical process of neurite outgrowth they must be linked to changes in cytoskeletal elements. Process formation in most neurons, including mature sensory neurons comprises several different stages, including the formation of lamellopodia, filopodia and eventual condensation into extending neurites. ${ }^{114,161}$ Such events require contributions from actin microfilaments and microtubules. These processes are regulated by the Rho GTPase family and ultimately affect multiple signaling pathways (see Figure 11). Three members of this family are Rho, $\mathrm{Rac}$ and $\mathrm{Cdc} 42$ and each control a signal transduction pathway linking membrane receptors to the assembly and disassembly of the actin cytoskeleton and of associated integrin adhesion complexes. Rho regulates stress fibre and focal adhesion assembly, Rac regulates the formation of lamellipodia protrusions and membrane ruffles, and $\mathrm{Cdc} 42$ triggers filopodial extensions at the cell periphery. ${ }^{162}$ Among downstream effectors of interest are LIMK, which is activated by
Rac/Cdc42 via PAK1, and Rho via Rho associated coiled-coil kinase, ROCK. ${ }^{163,164}$ These intermediates regulate actin polymerization status via cofilin and the related ADF (actin depolymerization factor), among other factors. Cofilin/ADF acts to sever and depolymerize actin filaments, and thus plays a key role in the rapid actin filament turnover, by providing a pool of actin monomers that can be rapidly recycled to undergo further rounds of polymerization. ${ }^{163-165}$ Cofilin is regulated by phosphorylation, with the phosphorylated form being inactive and unable to bind to actin, while dephosphorylation of this site restores the actin-depolymerizing activity. Cofilin is phosphorylated by LIMK in a Rho-dependent manner and by testicular kinase 1 (TESK1) in an integrin-dependent, but Rhoindependent manner. ${ }^{166-168}$ Dephosphorylation of cofilin is mediated by Slingshot phosphatase. ${ }^{169}$

Of interest in this regard are results regarding the role of the small heat shock protein 27 (Hsp27) in neurite growth from adult DRG neurons in vitro ${ }^{65,114,170} \mathrm{Hsp} 27$ is distributed throughout neuritic process and is found in growth cones and seems to be enriched at branch points of processes. ${ }^{114}$ Laminin stimulation of 
DRG neurons results in the phosphorylation of Hsp27, likely via the activation of p38 MAPK and its downstream target MAPKAP-K2 (see Figure 11). ${ }^{171}$ Hsp27 interacts with actin and modulates actin polymerization/ depolymerization dynamics. ${ }^{172-}$ ${ }^{174}$ It also interacts with neurofilaments and microtubules, and has been suggested to play a role in stabilizing the cytoskeleton; ${ }^{114,175,176}$ mutations in Hsp27 are associated with Charcot-Marie Tooth sensory neuropathy. ${ }^{176}$

Microtubules are also critical components of growth cone dynamics and are regulated by a variety of mechanisms including both neurotrophin and integrin-mediated events. ${ }^{152,161,177-182}$ Much of the work investigating the role of these intermediates in regulating axonal growth has been carried out in embryonic neurons, although some recent studies have begun to investigate their role in mature PNS neurons (eg., ${ }^{183,184}$ ). While an extensive analysis of the literature is beyond the scope of this review, the reader is referred to reviews that discuss the role of various downstream effectors in the regulation of axonal growth. . $^{3,67,165,179,185-189}$

\section{Conclusions}

Although many key environmental factors and upstream intracellular signaling intermediates involved in stimulating neurite growth of adult sensory DRG neurons have been identified, many questions remain. For instance, the specific interactions with downstream effectors have yet to be elucidated. As suggested above the Rho family of small GTPases (Rho, Rac, Cdc42, PAK1) and the actin binding proteins (Cofilin and LIMK) are key regulators of growth cone motility and axonal advancement, but we know little of role of these proteins in neurite growth of mature sensory neurons. From Figure 11 one could envision how the required signaling intermediates that have already been identified could possibly interact with potential downstream effectors that are essential for growth cone remodelling and axonal extension. For example, it is likely that PI-3K may activate Rac, resulting in the activation of Pak and subsequent inhibition of LIMK and myosin light chain kinase (MLCK, which regulates myosin-II), which are important for retrograde flow of actin and growth cone retraction. ${ }^{180,190,191}$ It has also been suggested that FAK, which we have shown to be activated by both NGF and LN, may inhibit activation of Rho and its downstream effector ROCK, thereby stimulating axonal elongatio. ${ }^{192}$ While many of these signaling events are being elucidated in non-neuronal cells, neuronal cell lines and embryonic primary neurons, it will still be some time before an integrated picture of the complex interactions between different ligand-mediated events emerges. Nonetheless the information presented above outlines the importance of the extracellular environment in axonal growth and regeneration especially in the peripheral sensory nervous system. By understanding elements that regulate axon growth in permissive environments, hopefully clues will emerge that can be used to overcome growth inhibition due to an inhibitory milieu or to the intrinsic properties of neurons.

\section{Abbreviations}

GDNF - Glial cell line-derived neurotrophic factor; GFR $\alpha$ GDNF family receptor $\alpha$; RET- REarranged during Transfection; BDNF- brain-derived neurotrophic factor; NT-3 - neurotrophin
3; IGF - insulin growth factor;VEGF - vascular endothelial growth factor; FGF - fibroblast growth factor; EGF- epidermal growth factor; TGF- $\beta$ - transforming growth factor- beta; GSK3 - glycogen synthase kinase 3; MAPK - Mitogen activated protein kinase; MEK- Mitogen activated protein kinase kinase; LIMK- LIM kinase; PLCg- phospholipase C-g; PI 3-K phosphatidylinositol 3-kinase; PKC - protein kinase C.

\section{ACKNOWLEDGEMENTS}

The authors thank past and current members of the Mearow lab (Masuma Rahimtula, Sherri Rankin, Kristy Williams, Michael King, Firoozeh Nafar, Elaine Dodge, David Jones, Kurt Kimpinski) for their contributions to the studies cited and for stimulating discussion. KMM is supported by operating funds from CIHR and NSERC; BAT was supported by NSERC (Canada Graduate Scholarship and NSERC Postdoctoral Fellowship).

\section{REFERENCES}

1. Meiners S, Mercado ML. Functional peptide sequences derived from extracellular matrix glycoproteins and their receptors: strategies to improve neuronal regeneration. Mol Neurobiol. 2003;27(2):177-96.

2. Nakamoto T, Kain KH, Ginsberg MH. Neurobiology: new connections between integrins and axon guidance. Curr Biol. 2004;14(3):R121-3.

3. Lemons ML, Condic ML. Integrin signaling is integral to regeneration. Exp Neurol. 2008;209:343-52.

4. Hoke A. Mechanisms of disease: what factors limit the success of peripheral nerve regeneration in humans? Nat Clin Pract Neurol. 2006;2(8):448-54.

5. Fenrich K, Gordon T. Canadian Association of Neuroscience review: axonal regeneration in the peripheral and central nervous systems--current issues and advances. Can J Neurol Sci. 2004;31(2): 142-56.

6. Lundborg G, Rosen B. Hand function after nerve repair. Acta Physiol (Oxf). 2007;189(2):207-17.

7. Navarro X, Vivo M, Valero-Cabre A. Neural plasticity after peripheral nerve injury and regeneration. Prog Neurobiol. 2007;82(4): 163-201.

8. Aguayo AJ, David S, Bray GM. Influences of the glial environment on the elongation of axons after injury: transplantation studies in adult rodents. J Exp Biol. 1981;95:231-40.

9. Aguayo AJ, Rasminsky M, Bray GM, Carbonetto S, McKerracher L, Villegas-Perez MP, et al. Degenerative and regenerative responses of injured neurons in the central nervous system of adult mammals. Philos Trans R Soc Lond B Biol Sci. 1991; 331(1261):337-43

10. David S, Aguayo AJ. Axonal elongation into peripheral nervous system "bridges" after central nervous system injury in adult rats. Science. 1981;214(4523):931-3.

11. Filbin MT. Myelin-associated inhibitors of axonal regeneration in the adult mammalian CNS. Nat Rev Neurosci. 2003;4(9): 703-13.

12. McKerracher L, David S, Jackson DL, Kottis V, Dunn RJ, Braun PE. Identification of myelin-associated glycoprotein as a major myelin-derived inhibitor of neurite growth. Neuron. 1994;13(4): 805-11.

13. Chen MS, Huber AB, van der Haar ME, Frank M, Schnell L, Spillmann AA, et al. Nogo-A is a myelin-associated neurite outgrowth inhibitor and an antigen for monoclonal antibody IN1. Nature. 2000;403(6768):434-9.

14. GrandPre T, Nakamura F, Vartanian T, Strittmatter SM. Identification of the Nogo inhibitor of axon regeneration as a Reticulon protein. Nature. 2000;403(6768):439-44.

15. Cafferty WB, Yang SH, Duffy PJ, Li S, Strittmatter SM. Functional axonal regeneration through astrocytic scar genetically modified to digest chondroitin sulfate proteoglycans. J Neurosci. 2007; 27(9):2176-85 
16. Galtrey CM, Fawcett JW. The role of chondroitin sulfate proteoglycans in regeneration and plasticity in the central nervous system. Brain Res Rev. 2007;54(1):1-18.

17. Liu BP, Cafferty WB, Budel SO, Strittmatter SM. Extracellular regulators of axonal growth in the adult central nervous system. Philos Trans R Soc Lond B Biol Sci. 2006;361(1473):1593-610.

18. Lemons ML, Barua S, Abanto ML, Halfter W, Condic ML. Adaptation of sensory neurons to hyalectin and decorin proteoglycans. J Neurosci. 2005;25(20):4964-73.

19. David S, Braun PE, Jackson DL, Kottis V, McKerracher L. Laminin overrides the inhibitory effects of peripheral nervous system and central nervous system myelin-derived inhibitors of neurite growth. J Neurosci Res. 1995;42(4):594-602.

20. Grimpe B, Silver J. The extracellular matrix in axon regeneration. Prog Brain Res. 2002;137:333-49.

21. Fu SY, Gordon T. The cellular and molecular basis of peripheral nerve regeneration. Mol Neurobiol. 1997;14(1-2):67-116.

22. McKerracher L, Chamoux M, Arregui CO. Role of laminin and integrin interactions in growth cone guidance. Mol Neurobiol. 1996;12(2):95-116.

23. Vogelezang MG, Liu Z, Relvas JB, Raivich G, Scherer SS, ffrenchConstant C. Alpha4 integrin is expressed during peripheral nerve regeneration and enhances neurite outgrowth. J Neurosci. 2001;21(17):6732-44.

24. Vogelezang MG, Scherer SS, Fawcett JW, ffrench-Constant C. Regulation of fibronectin alternative splicing during peripheral nerve repair. J Neurosci Res. 1999;56(4):323-33.

25. Kim SM, Lee SK, Lee JH. Peripheral nerve regeneration using a three dimensionally cultured schwann cell conduit. J Craniofac Surg. 2007; 18(3):475-88.

26. Dornseifer U, Matiasek K, Fichter MA, Rupp A, Henke J, Weidner $\mathrm{N}$, et al. Surgical therapy of peripheral nerve lesions: current status and new perspectives. Zentralbl Neurochir. 2007;68(3): $101-10$.

27. Yang Y, Ding F, Wu J, Hu W, Liu W, Liu J, et al. Development and evaluation of silk fibroin-based nerve grafts used for peripheral nerve regeneration. Biomaterials. 2007;28(36):5526-35.

28. Haastert K, Grothe C. Gene therapy in peripheral nerve reconstruction approaches. Curr Gene Ther. 2007;7(3):221-8.

29. Devor M. Unexplained peculiarities of the dorsal root ganglion. Pain. 1999;Suppl 6:S27-35.

30. Priestley JV, Michael GJ, Averill S, Liu M, Willmott N. Regulation of nociceptive neurons by nerve growth factor and glial cell line derived neurotrophic factor. Can J Physiol Pharmacol. 2002; 80(5):495-505.

31. Petruska JC, Napaporn J, Johnson RD, Gu JG, Cooper BY. Subclassified acutely dissociated cells of rat DRG: histochemistry and patterns of capsaicin-, proton-, and ATP-activated currents. J Neurophysiol. 2000;84(5):2365-79.

32. Gavazzi I, Kumar RD, McMahon SB, Cohen J. Growth responses of different subpopulations of adult sensory neurons to neurotrophic factors in vitro. Eur J Neurosci. 1999;11(10): 3405-14.

33. Averill S, McMahon SB, Clary DO, Reichardt LF, Priestley JV. Immunocytochemical localization of trkA receptors in chemically identified subgroups of adult rat sensory neurons. Eur J Neurosci. 1995; 7(7):1484-94.

34. Ishikawa T, Miyagi M, Ohtori S, Aoki Y, Ozawa T, Doya H, et al. Characteristics of sensory DRG neurons innervating the lumbar facet joints in rats. Eur Spine J. 2005;14(6):559-64.

35. Tucker BA, Rahimtula M, Mearow KM. Laminin and growth factor receptor activation stimulates differential growth responses in subpopulations of adult DRG neurons. Eur J Neurosci. 2006; 24(3):676-90.

36. Ramer MS, Bradbury EJ, Michael GJ, Lever IJ, McMahon SB. Glial cell line-derived neurotrophic factor increases calcitonin gene-related peptide immunoreactivity in sensory and motoneurons in vivo. Eur J Neurosci. 2003;18(10):2713-21.

37. Molliver DC, Wright DE, Leitner ML, Parsadanian AS, Doster K, Wen D, et al. IB4-binding DRG neurons switch from NGF to GDNF dependence in early postnatal life. Neuron. 1997;19(4): 849-61.
38. Bennett DL, Michael GJ, Ramachandran N, Munson JB, Averill S, Yan Q, et al. A distinct subgroup of small DRG cells express GDNF receptor components and GDNF is protective for these neurons after nerve injury. J Neurosci. 1998;18(8):3059-72.

39. Kashiba H, Uchida Y, Senba E. Distribution and colocalization of NGF and GDNF family ligand receptor mRNAs in dorsal root and nodose ganglion neurons of adult rats. Brain Res Mol Brain Res. 2003;110(1):52-62.

40. Karchewski LA, Kim FA, Johnston J, McKnight RM, Verge VM. Anatomical evidence supporting the potential for modulation by multiple neurotrophins in the majority of adult lumbar sensory neurons. J Comp Neurol. 1999;413(2):327-41.

41. Kashiba H, Noguchi K, Ueda Y, Senba E. Coexpression of trk family members and low-affinity neurotrophin receptors in rat dorsal root ganglion neurons. Brain Res Mol Brain Res. 1995;30(1):158-64.

42. Kashiba H, Ueda Y, Ueyama T, Nemoto K, Senba E. Relationship between BDNF- and trk-expressing neurones in rat dorsal root ganglion: an analysis by in situ hybridization. Neuroreport. 1997;8(5):1229-34.

43. McMahon SB, Armanini MP, Ling LH, Phillips HS. Expression and coexpression of Trk receptors in subpopulations of adult primary sensory neurons projecting to identified peripheral targets. Neuron. 1994;12(5): 1161-71.

44. Kimpinski K, Campenot RB, Mearow K. Effects of the neurotrophins nerve growth factor, neurotrophin-3, and brainderived neurotrophic factor (BDNF) on neurite growth from adult sensory neurons in compartmented cultures. J Neurobiol. 1997;33(4):395-410

45. Lee R, Kermani P, Teng KK, Hempstead BL. Regulation of cell survival by secreted proneurotrophins. Science. 2001;294(5548): 1945-8.

46. Bandtlow C, Dechant G. From cell death to neuronal regeneration, effects of the p75 neurotrophin receptor depend on interactions with partner subunits. Sci STKE. 2004;2004(235):pe24.

47. Barker PA. p75NTR is positively promiscuous: novel partners and new insights. Neuron. 2004;42(4):529-33.

48. Hasegawa Y, Yamagishi S, Fujitani M, Yamashita T. p75 Neurotrophin receptor signaling in the nervous system. Biotechnol Annu Rev. 2004;10:123-49.

49. Hennigan A, O'Callaghan RM, Kelly AM. Neurotrophins and their receptors: roles in plasticity, neurodegeneration and neuroprotection. Biochem Soc Trans. 2007;35(Pt 2):424-7.

50. Lu B, Pang PT, Woo NH. The yin and yang of neurotrophin action. Nat Rev Neurosci. 2005;6(8):603-14.

51. Twiss JL, Chang JH, Schanen NC. Pathophysiological mechanisms for actions of the neurotrophins. Brain Pathol. 2006;16(4): 320-32.

52. Airaksinen MS, Saarma M. The GDNF family: signalling, biological functions and therapeutic value. Nat Rev Neurosci. 2002;3(5):383-94.

53. Runeberg-Roos P, Saarma M. Neurotrophic factor receptor RET: structure, cell biology, and inherited diseases. Ann Med. 2007: 39:572-80.

54. McMahon SB, Priestley JV. Peripheral neuropathies and neurotrophic factors: animal models and clinical perspectives. Curr Opin Neurobiol. 1995;5(5):616-24.

55. Durbec P, Marcos-Gutierrez CV, Kilkenny C, Grigoriou M, Wartiowaara K, Suvanto P, et al. GDNF signalling through the Ret receptor tyrosine kinase. Nature. 1996;381(6585):789-93.

56. Treanor JJ, Goodman L, de Sauvage F, Stone DM, Poulsen KT, Beck CD, et al. Characterization of a multicomponent receptor for GDNF. Nature. 1996;382(6586):80-3.

57. Trupp M, Arenas E, Fainzilber M, Nilsson AS, Sieber BA, Grigoriou M, et al. Functional receptor for GDNF encoded by the c-ret proto-oncogene. Nature. 1996;381(6585):785-9.

58. Tonge D, Edstrom A, Ekstrom P. Use of explant cultures of peripheral nerves of adult vertebrates to study axonal regeneration in vitro. Prog Neurobiol. 1998;54(4):459-80.

59. Delree P, Ribbens C, Martin D, Rogister B, Lefebvre PP, Rigo JM, et al. Plasticity of developing and adult dorsal root ganglion neurons as revealed in vitro. Brain Res Bull. 1993;30(3-4): $231-7$. 
60. Tucker BA, Rahimtula M, Mearow KM. A procedure for selecting and culturing subpopulations of neurons from rat dorsal root ganglia using magnetic beads. Brain Res Brain Res Protoc. 2005; 16(1-3):50-7.

61. Smith DS, Skene JH. A transcription-dependent switch controls competence of adult neurons for distinct modes of axon growth. J Neurosci. 1997;17(2):646-58

62. Lankford KL, Waxman SG, Kocsis JD. Mechanisms of enhancement of neurite regeneration in vitro following a conditioning sciatic nerve lesion. J Comp Neurol. 1998;391(1): 11-29.

63. White FA, Keller-Peck CR, Knudson CM, Korsmeyer SJ, Snider WD. Widespread elimination of naturally occurring neuronal death in Bax-deficient mice. J Neurosci. 1998;18(4):1428-39.

64. Lindsay RM. Nerve growth factors (NGF, BDNF) enhance axonal regeneration but are not required for survival of adult sensory neurons. J Neurosci. 1988;8(7):2394-405.

65. Williams KL, Rahimtula M, Mearow KM. Heat shock protein 27 is involved in neurite extension and branching of dorsal root ganglion neurons in vitro. J Neurosci Res. 2006;84(4):716-23.

66. Dodge ME, Rahimtula M, Mearow KM. Factors contributing to neurotrophin-independent survival of adult sensory neurons. Brain Res. 2002;953(1-2):144-56.

67. Chen ZL, Yu WM, Strickland S. Peripheral regeneration. Annu Rev Neurosci. 2007;30:209-33.

68. Lykissas MG, Batistatou AK, Charalabopoulos KA, Beris AE. The role of neurotrophins in axonal growth, guidance, and regeneration. Curr Neurovasc Res. 2007;4(2):143-51.

69. Ekstrom AR, Kanje M, Skottner A. Nerve regeneration and serum levels of insulin-like growth factor-I in rats with streptozotocininduced insulin deficiency. Brain Res. 1989;496(1-2):141-7.

70. Jones DM, Tucker BA, Rahimtula M, Mearow KM. The synergistic effects of NGF and IGF-1 on neurite growth in adult sensory neurons: convergence on the PI 3-kinase signaling pathway. J Neurochem. 2003;86(5):1116-28

71. Kimpinski K, Mearow K. Neurite growth promotion by nerve growth factor and insulin-like growth factor-1 in cultured adult sensory neurons: role of phosphoinositide 3-kinase and mitogen activated protein kinase. J Neurosci Res. 2001;63(6):486-99.

72. Fernyhough P, Willars GB, Lindsay RM, Tomlinson DR. Insulin and insulin-like growth factor I enhance regeneration in cultured adult rat sensory neurones. Brain Res. 1993;607(1-2):117-24.

73. Akahori Y, Horie H. IGF-I enhances neurite regeneration but is not required for its survival in adult DRG explant. Neuroreport. 1997;8(9-10):2265-9.

74. Haastert K, Lipokatic E, Fischer M, Timmer M, Grothe C. Differentially promoted peripheral nerve regeneration by grafted Schwann cells over-expressing different FGF-2 isoforms. Neurobiol Dis. 2006;21(1):138-53.

75. Malgrange B, Delree P, Rigo JM, Baron H, Moonen G. Image analysis of neuritic regeneration by adult rat dorsal root ganglion neurons in culture: quantification of the neurotoxicity of anticancer agents and of its prevention by nerve growth factor or basic fibroblast growth factor but not brain-derived neurotrophic factor or neurotrophin-3. J Neurosci Methods. 1994;53(1): $111-22$.

76. Mohiuddin L, Fernyhough P, Tomlinson DR. Acidic fibroblast growth factor enhances neurite outgrowth and stimulates expression of GAP-43 and T alpha 1 alpha-tubulin in cultured neurones from adult rat dorsal root ganglia. Neurosci Lett. 1996; 215(2):111-4

77. Sondell M, Sundler F, Kanje M. Vascular endothelial growth factor is a neurotrophic factor which stimulates axonal outgrowth through the flk-1 receptor. Eur J Neurosci. 2000;12(12):4243-54.

78. Nilsson A, Kanje M. Amphiregulin acts as an autocrine survival factor for adult sensory neurons. Neuroreport. 2005;16(3):213-8.

79. Chalazonitis A, Kalberg J, Twardzik DR, Morrison RS, Kessler JA. Transforming growth factor beta has neurotrophic actions on sensory neurons in vitro and is synergistic with nerve growth factor. Dev Biol. 1992;152(1):121-32.
80. Niwa H, Hayakawa K, Yamamoto M, Itoh T, Mitsuma T, Sobue G. Differential age-dependent trophic responses of nodose, sensory, and sympathetic neurons to neurotrophins and GDNF: potencies for neurite extension in explant culture. Neurochem Res. 2002; 27(6):485-96.

81. Kimpinski K, Jelinski S, Mearow K. The anti-p75 antibody, MC192, and brain-derived neurotrophic factor inhibit nerve growth factor-dependent neurite growth from adult sensory neurons. Neuroscience. 1999;93(1):253-263.

82. Kaplan DR, Miller FD. Signal transduction by the neurotrophin receptors. Curr Opin Cell Biol. 1997;9(2):213-21.

83. Kaplan DR, Miller FD. Neurotrophin signal transduction in the nervous system. Curr Opin Neurobiol. 2000;10(3):381-91.

84. Markus A, Patel TD, Snider WD. Neurotrophic factors and axonal growth. Curr Opin Neurobiol. 2002;12(5):523-31.

85. Reichardt LF. Neurotrophin-regulated signalling pathways. Philos Trans R Soc Lond B Biol Sci. 2006;361(1473):1545-64

86. Atwal JK, Massie B, Miller FD, Kaplan DR. The TrkB-She site signals neuronal survival and local axon growth via MEK and P13-kinase. Neuron. 2000;27(2):265-77.

87. Cafferty WB, Gardiner NJ, Gavazzi I, Powell J, McMahon SB, Heath $\mathrm{JK}$, et al. Leukemia inhibitory factor determines the growth status of injured adult sensory neurons. J Neurosci. 2001; 21(18):7161-70.

88. Edstrom A, Ekstrom PA. Role of phosphatidylinositol 3-kinase in neuronal survival and axonal outgrowth of adult mouse dorsal root ganglia explants. J Neurosci Res. 2003;74(5):726-35.

89. Liu RY, Snider WD. Different signaling pathways mediate regenerative versus developmental sensory axon growth. J Neurosci. 2001;21(17):RC164.

90. Wiklund P, Ekstrom PA, Edbladh M, Tonge D, Edstrom A. Protein kinase $\mathrm{C}$ and mouse sciatic nerve regeneration. Brain Res. 1996;715(1-2):145-54.

91. Wiklund P, Ekstrom PA, Edstrom A. Mitogen-activated protein kinase inhibition reveals differences in signalling pathways activated by neurotrophin-3 and other growth-stimulating conditions of adult mouse dorsal root ganglia neurons. J Neurosci Res. 2002;67(1):62-8

92. Edstrom A, Ekstrom PA, Tonge D. Axonal outgrowth and neuronal apoptosis in cultured adult mouse dorsal root ganglion preparations: effects of neurotrophins, of inhibition of neurotrophin actions and of prior axotomy. Neuroscience. 1996; 75(4):1165-74

93. Eickholt BJ, Ahmed AI, Davies M, Papakonstanti EA, Pearce W, Starkey ML, et al. Control of axonal growth and regeneration of sensory neurons by the p110delta PI 3-Kinase. PLoS ONE. 2007;2(9):e869.

94. Tucker BA, Rahimtula M, Mearow KM. Integrin activation and neurotrophin signaling cooperate to enhance neurite outgrowth in sensory neurons. J Comp Neurol. 2005;486(3):267-80.

95. Tucker BA, Rahimtula M, Mearow KM. Src and FAK are key early signalling intermediates required for neurite growth in NGFresponsive adult DRG neurons. Cell Signal. 2008;20(1):241-57.

96. Ganju P, O'Bryan JP, Der C, Winter J, James IF. Differential regulation of SHC proteins by nerve growth factor in sensory neurons and PC12 cells. Eur J Neurosci. 1998;10(6):1995-2008.

97. Seijffers R, Mills CD, Woolf CJ. ATF3 increases the intrinsic growth state of DRG neurons to enhance peripheral nerve regeneration. J Neurosci. 2007;27(30):7911-20.

98. Lindwall C, Kanje M. The Janus role of c-Jun: cell death versus survival and regeneration of neonatal sympathetic and sensory neurons. Exp Neurol. 2005;196(1):184-94.

99. Stam FJ, MacGillavry HD, Armstrong NJ, de Gunst MC, Zhang Y, van Kesteren RE, et al. Identification of candidate transcriptional modulators involved in successful regeneration after nerve injury. Eur J Neurosci. 2007;25(12):3629-37.

100. Chen ZL, Strickland S. Laminin gamma1 is critical for Schwann cell differentiation, axon myelination, and regeneration in the peripheral nerve. J Cell Biol. 2003;163(4):889-99.

101.Liuzzi FJ, Tedeschi B. Peripheral nerve regeneration. Neurosurg Clin N Am. 1991;2(1):31-42. 
102. Matesz C, Modis L, Halasi G, Szigeti ZM, Felszeghy S, Bacskai T, et al. Extracellular matrix molecules and their possible roles in the regeneration of frog nervous system. Brain Res Bull. 2005;66(4-6):526-31.

103.Loers G, Schachner M. Recognition molecules and neural repair. J Neurochem. 2007;101(4):865-82.

104. Yamaguchi Y. Heparan sulfate proteoglycans in the nervous system: their diverse roles in neurogenesis, axon guidance, and synaptogenesis. Semin Cell Dev Biol. 2001;12(2):99-106.

105.Luckenbill-Edds L. Laminin and the mechanism of neuronal outgrowth. Brain Res Brain Res Rev. 1997;23(1-2):1-27.

106. Colognato $\mathrm{H}$, ffrench-Constant $\mathrm{C}$, Feltri ML. Human diseases reveal novel roles for neural laminins. Trends Neurosci. 2005; 28(9):480-6.

107. Bunge RP, Bunge MB, Eldridge CF. Linkage between axonal ensheathment and basal lamina production by Schwann cells. Annu Rev Neurosci. 1986;9:305-28.

108. Ekstrom PA, Mayer U, Panjwani A, Pountney D, Pizzey J, Tonge DA. Involvement of alpha7betal integrin in the conditioninglesion effect on sensory axon regeneration. Mol Cell Neurosci. 2003;22(3):383-95.

109. Tonge DA, Golding JP, Edbladh M, Kroon M, Ekstrom PE, Edstrom A. Effects of extracellular matrix components on axonal outgrowth from peripheral nerves of adult animals in vitro. Exp Neurol. 1997;146(1):81-90.

110. Carbonetto S, Cochard P. In vitro studies on the control of nerve fiber growth by the extracellular matrix of the nervous system. J Physiol (Paris). 1987;82(4):258-70.

111. Itoh T, Sobue G, Yasuda T, Mitsuma T, Takahashi A, Kimata K. Geometry of adult rat sensory neurons in culture; its modulation by laminin. Neurosci Lett. 1991;123(2):212-6.

112. Kohno K, Kawakami T, Hiruma H. Effects of soluble laminin on organelle transport and neurite growth in cultured mouse dorsal root ganglion neurons: difference between primary neurites and branches. J Cell Physiol. 2005;205(2):253-61.

113. Unsicker K, Skaper SD, Davis GE, Manthorpe M, Varon S. Comparison of the effects of laminin and the polyornithinebinding neurite promoting factor from RN22 Schwannoma cells on neurite regeneration from cultured newborn and adult rat dorsal root ganglion neurons. Brain Res. 1985;349(1-2):304-8.

114. Williams KL, Rahimtula M, Mearow KM. Hsp27 and axonal growth in adult sensory neurons in vitro. BMC Neurosci. 2005; 6(1):24 .

115. Paveliev M, Lume M, Velthut A, Phillips M, Arumae U, Saarma M. Neurotrophic factors switch between two signaling pathways that trigger axonal growth. J Cell Sci. 2007;120(Pt 15):2507-16.

116. Deister C, Aljabari S, Schmidt CE. Effects of collagen 1, fibronectin, laminin and hyaluronic acid concentration in multicomponent gels on neurite extension. J Biomater Sci Polym Ed. 2007;18(8):983-97.

117. Gardiner NJ, Moffatt S, Fernyhough P, Humphries MJ, Streuli CH, Tomlinson DR. Preconditioning injury-induced neurite outgrowth of adult rat sensory neurons on fibronectin is mediated by mobilisation of axonal alpha5 integrin. Mol Cell Neurosci. 2007;35(2):249-60.

118. Giancotti FG, Tarone G. Positional control of cell fate through joint integrin/receptor protein kinase signaling. Annu Rev Cell Dev Biol. 2003;19:173-206.

119. Giancotti FG. A structural view of integrin activation and signaling. Dev Cell. 2003;4(2):149-51.

120.Guo W, Giancotti FG. Integrin signalling during tumour progression. Nat Rev Mol Cell Biol. 2004;5(10):816-26.

121. Giancotti FG, Ruoslahti E. Integrin signaling. Science 1999; 285(5430):1028-32.

122. Hynes RO. Integrins: bidirectional, allosteric signaling machines. Cell. 2002;110(6):673-87

123.Previtali SC, Feltri ML, Archelos JJ, Quattrini A, Wrabetz L, Hartung $\mathrm{H}$. Role of integrins in the peripheral nervous system. Prog Neurobiol. 2001;64(1):35-49.

124. Archelos JJ, Previtali SC, Hartung HP. The role of integrins in immune-mediated diseases of the nervous system. Trends Neurosci. 1999;22(1):30-8.
125. Hynes RO. Integrins: versatility, modulation, and signaling in cell adhesion. Cell. 1992;69(1):11-25.

126. Eble JA, Haier J. Integrins in cancer treatment. Curr Cancer Drug Targets. 2006;6(2):89-105.

127.Lenz HJ. Antiangiogenic agents in cancer therapy. Oncology (Williston Park). 2005;19(4 Suppl 3):17-25.

128. Serini G, Valdembri D, Bussolino F. Integrins and angiogenesis: a sticky business. Exp Cell Res. 2006;312(5):651-8.

129. Caswell PT, Norman JC. Integrin trafficking and the control of cell migration. Traffic. 2006;7(1):14-21.

130. Condic ML. Adult neuronal regeneration induced by transgenic integrin expression. J Neurosci. 2001;21(13):4782-8.

131. Tomaselli KJ, Doherty P, Emmett CJ, Damsky CH, Walsh FS, Reichardt LF. Expression of beta 1 integrins in sensory neurons of the dorsal root ganglion and their functions in neurite outgrowth on two laminin isoforms. J Neurosci. 1993;13(11): 4880-8.

132. Gardiner NJ, Fernyhough P, Tomlinson DR, Mayer U, von der Mark $\mathrm{H}$, Streuli $\mathrm{CH}$. Alpha7 integrin mediates neurite outgrowth of distinct populations of adult sensory neurons. Mol Cell Neurosci. 2005;28(2):229-40.

133. Condic ML, Letourneau PC. Ligand-induced changes in integrin expression regulate neuronal adhesion and neurite outgrowth. Nature. 1997;389(6653):852-6.

134. Guan W, Puthenveedu MA, Condic ML. Sensory neuron subtypes have unique substratum preference and receptor expression before target innervation. J Neurosci 2003;23(5):1781-91.

135. Leclere PG, Norman E, Groutsi F, Coffin R, Mayer U, Pizzey J, et al. Impaired axonal regeneration by isolectin B4-binding dorsal root ganglion neurons in vitro. J Neurosci. 2007;27(5):1190-9.

136. Wallquist W, Zelano J, Plantman S, Kaufman SJ, Cullheim S, Hammarberg H. Dorsal root ganglion neurons up-regulate the expression of laminin-associated integrins after peripheral but not central axotomy. J Comp Neurol. 2004;480(2):162-9.

137. Arnaout MA, Goodman SL, Xiong JP. Structure and mechanics of integrin-based cell adhesion. Curr Opin Cell Biol. 2007;19(5):495-507.

138. Aplin AE, Howe AK, Juliano RL. Cell adhesion molecules, signal transduction and cell growth. Curr Opin Cell Biol. 1999;11(6):737-44.

139. Travis MA, Humphries JD, Humphries MJ. An unraveling tale of how integrins are activated from within. Trends Pharmacol Sci. 2003;24(4): 192-7.

140. Ginsberg MH, Partridge A, Shattil SJ. Integrin regulation. Curr Opin Cell Biol. 2005;17(5):509-16.

141. Chen HC, Appeddu PA, Isoda H, Guan JL. Phosphorylation of tyrosine 397 in focal adhesion kinase is required for binding phosphatidylinositol 3-kinase. J Biol Chem. 1996;271(42): 26329-34.

142. Wary KK, Mainiero F, Isakoff SJ, Marcantonio EE, Giancotti FG. The adaptor protein Shc couples a class of integrins to the control of cell cycle progression. Cell. 1996;87(4):733-43.

143. Wary KK, Mariotti A, Zurzolo C, Giancotti FG. A requirement for caveolin-1 and associated kinase Fyn in integrin signaling and anchorage-dependent cell growth. Cell. 1998;94(5):625-34.

144. Hannigan GE, Leung-Hagesteijn C, Fitz-Gibbon L, Coppolino MG, Radeva G, Filmus J, et al. Regulation of cell adhesion and anchorage-dependent growth by a new beta 1-integrin-linked protein kinase. Nature. 1996;379(6560):91-6.

145. Kornberg L, Earp HS, Parsons JT, Schaller M, Juliano RL. Cell adhesion or integrin clustering increases phosphorylation of a focal adhesion-associated tyrosine kinase. J Biol Chem. 1992; 267(33):23439-42

146. Schaller MD, Parsons JT. Focal adhesion kinase and associated proteins. Curr Opin Cell Biol. 1994;6(5):705-10.

147. Howe A, Aplin AE, Alahari SK, Juliano RL. Integrin signaling and cell growth control. Curr Opin Cell Biol. 1998;10(2):220-31.

148. Alam N, Goel HL, Zarif MJ, Butterfield JE, Perkins HM, Sansoucy $\mathrm{BG}$, et al. The integrin-growth factor receptor duet. J Cell Physiol. 2007;213(3):649-53.

149. Delcroix JD, Valletta JS, Wu C, Hunt SJ, Kowal AS, Mobley WC. NGF signaling in sensory neurons: evidence that early endosomes carry NGF retrograde signals. Neuron. 2003;39(1): 
69-84

150. Mills J, Digicaylioglu M, Legg AT, Young CE, Young SS, Barr AM, et al. Role of integrin-linked kinase in nerve growth factorstimulated neurite outgrowth. J Neurosci. 2003;23(5):1638-48.

151. Markus A, Zhong J, Snider WD. Raf and akt mediate distinct aspects of sensory axon growth. Neuron. 2002;35(1):65-76.

152.Zhou FQ, Zhou J, Dedhar S, Wu YH, Snider WD. NGF-induced axon growth is mediated by localized inactivation of GSK-3beta and functions of the microtubule plus end binding protein APC. Neuron. 2004;42(6):897-912.

153. Higuchi M, Onishi K, Masuyama N, Gotoh Y. The phosphatidylinositol-3 kinase (PI3K)-Akt pathway suppresses neurite branch formation in NGF-treated PC12 cells. Genes Cells. 2003;8(8):657-69.

154. Kamata Y, Shiraga H, Tai A, Kawamoto Y, Gohda E. Induction of neurite outgrowth in PC12 cells by the medium-chain fatty acid octanoic acid. Neuroscience. 2007;146(3): 1073-81.

155. Gary DS, Mattson MP. Integrin signaling via the PI3-kinase-Akt pathway increases neuronal resistance to glutamate-induced apoptosis. J Neurochem. 2001;76(5):1485-96.

156. Koul D, Shen R, Bergh S, Lu Y, de Groot JF, Liu TJ, et al. Targeting integrin-linked kinase inhibits Akt signaling pathways and decreases tumor progression of human glioblastoma. Mol Cancer Ther. 2005;4(11):1681-8.

157. Dey N, Howell BW, De PK, Durden DL. CSK negatively regulates nerve growth factor induced neural differentiation and augments AKT kinase activity. Exp Cell Res. 2005;307(1):1-14.

158. Schlaepfer DD, Hunter T. Integrin signalling and tyrosine phosphorylation: just the FAKs? Trends Cell Biol. 1998;8(4): $151-7$

159. Dikic I, Tokiwa G, Lev S, Courtneidge SA, Schlessinger J. A role for Pyk2 and Src in linking G-protein-coupled receptors with MAP kinase activation. Nature. 1996;383(6600):547-50.

160. Clark EA, Brugge JS. Integrins and signal transduction pathways: the road taken. Science. 1995;268(5208):233-9.

161.da Silva JS, Dotti CG. Breaking the neuronal sphere: regulation of the actin cytoskeleton in neuritogenesis. Nat Rev Neurosci. 2002;3(9):694-704.

162. Hall A. Rho GTPases and the control of cell behaviour. Biochem Soc Trans. 2005;33(Pt 5):891-5.

163. Huang TY, DerMardirossian C, Bokoch GM. Cofilin phosphatases and regulation of actin dynamics. Curr Opin Cell Biol. 2006; 18(1):26-31.

164. Sarmiere PD, Bamburg JR. Regulation of the neuronal actin cytoskeleton by ADF/cofilin. J Neurobiol. 2004;58(1):103-17.

165. Gallo G, Letourneau PC. Regulation of growth cone actin filaments by guidance cues. J Neurobiol. 2004;58(1):92-102.

166. Toshima J, Toshima JY, Amano T, Yang N, Narumiya S, Mizuno K. Cofilin phosphorylation by protein kinase testicular protein kinase 1 and its role in integrin-mediated actin reorganization and focal adhesion formation. Mol Biol Cell. 2001;12(4): 1131-45.

167. Ohashi K, Nagata K, Maekawa M, Ishizaki T, Narumiya S, Mizuno $\mathrm{K}$. Rho-associated kinase ROCK activates LIM-kinase 1 by phosphorylation at threonine 508 within the activation loop. J Biol Chem. 2000;275(5):3577-82.

168. Yang N, Higuchi O, Ohashi K, Nagata K, Wada A, Kangawa K, et al. Cofilin phosphorylation by LIM-kinase 1 and its role in Racmediated actin reorganization. Nature. 1998;393(6687):809-12 .

169. Ohta Y, Kousaka K, Nagata-Ohashi K, Ohashi K, Muramoto A, Shima Y, et al. Differential activities, subcellular distribution and tissue expression patterns of three members of Slingshot family phosphatases that dephosphorylate cofilin. Genes Cells. 2003; 8(10):811-24

170. Costigan M, Mannion RJ, Kendall G, Lewis SE, Campagna JA, Coggeshall RE, et al. Heat shock protein 27: developmental regulation and expression after peripheral nerve injury. $\mathrm{J}$ Neurosci. 1998;18(15):5891-900.

171. Guay J, Lambert H, Gingras-Breton G, Lavoie JN, Huot J, Landry J. Regulation of actin filament dynamics by p38 map kinasemediated phosphorylation of heat shock protein 27. J Cell Sci.
1997;110 (Pt 3):357-68.

172. Pichon S, Bryckaert M, Berrou E. Control of actin dynamics by $\mathrm{p} 38$ MAP kinase - Hsp27 distribution in the lamellipodium of smooth muscle cells. J Cell Sci. 2004;117(Pt 12):2569-77.

173. Mounier N, Arrigo AP. Actin cytoskeleton and small heat shock proteins: how do they interact? Cell Stress Chaperones. 2002; 7(2):167-76

174. During RL, Gibson BG, Li W, Bishai EA, Sidhu GS, Landry J, et al. Anthrax lethal toxin paralyzes actin-based motility by blocking Hsp27 phosphorylation. Embo J. 2007;26(9):2240-50.

175. Ackerley S, James PA, Kalli A, French S, Davies KE, Talbot K. A mutation in the small heat-shock protein HSPB1 leading to distal hereditary motor neuronopathy disrupts neurofilament assembly and the axonal transport of specific cellular cargoes. Hum Mol Genet. 2006;15(2):347-54.

176. Evgrafov OV, Mersiyanova I, Irobi J, Van Den Bosch L, Dierick I, Leung CL, et al. Mutant small heat-shock protein 27 causes axonal Charcot-Marie-Tooth disease and distal hereditary motor neuropathy. Nat Genet. 2004;36(6):602-6.

177. Dent EW, Gertler FB. Cytoskeletal dynamics and transport in growth cone motility and axon guidance. Neuron. 2003;40(2): 209-27.

178. Gallo G, Letourneau PC. Neurotrophins and the dynamic regulation of the neuronal cytoskeleton. J Neurobiol. 2000;44(2):159-73.

179. Gordon-Weeks PR. Microtubules and growth cone function. J Neurobiol. 2004;58(1):70-83.

180. Ketschek AR, Jones SL, Gallo G. Axon extension in the fast and slow lanes: substratum-dependent engagement of myosin II functions. Dev Neurobiol. 2007;67(10):1305-20.

181. Dehmelt L, Halpain S. Actin and microtubules in neurite initiation: are MAPs the missing link? J Neurobiol. 2004;58(1):18-33.

182. Halpain S, Dehmelt L. The MAP1 family of microtubule-associated proteins. Genome Biol. 2006;7(6):224.

183. Ahmed Z, Mazibrada G, Seabright RJ, Dent RG, Berry M, Logan A. TACE-induced cleavage of $\mathrm{NgR}$ and $\mathrm{p} 75 \mathrm{NTR}$ in dorsal root ganglion cultures disinhibits outgrowth and promotes branching of neurites in the presence of inhibitory CNS myelin. Faseb J. 2006;20(11):1939-41

184. Hiraga A, Kuwabara S, Doya H, Kanai K, Fujitani M, Taniguchi J, et al. Rho-kinase inhibition enhances axonal regeneration after peripheral nerve injury. J Peripher Nerv Syst. 2006;11(3): 217-24.

185. Gaillard S, Nasarre C, Gonthier B, Bagnard D. [The cellular and molecular basis of axonal growth]. Rev Neurol (Paris). 2005; 161(2):153-72.

186. Gungabissoon RA, Bamburg JR. Regulation of growth cone actin dynamics by ADF/cofilin. J Histochem Cytochem. 2003;51(4): 411-20.

187. Lundquist EA. Rac proteins and the control of axon development. Curr Opin Neurobiol. 2003;13(3):384-90.

188. Ng J, Luo L. Rho GTPases regulate axon growth through convergent and divergent signaling pathways. Neuron. 2004; 44(5):779-93

189. Sandvig A, Berry M, Barrett LB, Butt A, Logan A. Myelin-, reactive glia-, and scar-derived CNS axon growth inhibitors: expression, receptor signaling, and correlation with axon regeneration. Glia. 2004;46(3):225-51.

190. Huber AB, Kolodkin AL, Ginty DD, Cloutier JF. Signaling at the growth cone: ligand-receptor complexes and the control of axon growth and guidance. Annu Rev Neurosci. 2003;26:509-63.

191.Loudon RP, Silver LD, Yee HF, Jr., Gallo G. RhoA-kinase and myosin II are required for the maintenance of growth cone polarity and guidance by nerve growth factor. J Neurobiol. 2006;66(8):847-67.

192. Ren XD, Kiosses WB, Sieg DJ, Otey CA, Schlaepfer DD, Schwartz MA. Focal adhesion kinase suppresses Rho activity to promote focal adhesion turnover. J Cell Sci. 2000;113 (Pt 20):3673-8. 